\title{
Of mice and men: models and mechanisms of diabetic cardiomyopathy
}

\author{
Christian Riehle ${ }^{1}$ Johann Bauersachs ${ }^{1}$
}

Received: 11 October 2018 / Accepted: 9 November 2018 / Published online: 15 November 2018

(c) The Author(s) 2018

\begin{abstract}
Diabetes mellitus increases the risk of heart failure independent of co-existing hypertension and coronary artery disease. Although several molecular mechanisms for the development of diabetic cardiomyopathy have been identified, they are incompletely understood. The pathomechanisms are multifactorial and as a consequence, no causative treatment exists at this time to modulate or reverse the molecular changes contributing to accelerated cardiac dysfunction in diabetic patients. Numerous animal models have been generated, which serve as powerful tools to study the impact of type 1 and type 2 diabetes on the heart. Despite specific limitations of the models generated, they mimic various perturbations observed in the diabetic myocardium and continue to provide important mechanistic insight into the pathogenesis underlying diabetic cardiomyopathy. This article reviews recent studies in both diabetic patients and in these animal models, and discusses novel hypotheses to delineate the increased incidence of heart failure in diabetic patients.
\end{abstract}

Keywords Heart failure $\cdot$ Diabetes mellitus $\cdot$ Diabetic cardiomyopathy $\cdot$ Cardiac energetics $\cdot$ Mitochondria $\cdot$ Animal models

\section{Introduction}

The prevalence of diabetes is increasing at an alarming rate. Estimations by the World Health Organization (WHO) reported that 422 million adults were affected by diabetes in 2014, compared to 108 million in 1980. In 2004, 3.4 million people died due to complications associated with diabetes, and this number is expected to double by 2030 (www.who. int). There are two predominant types of diabetes; type 1 diabetes (T1D) is characterized by impaired insulin production and insulinopenia as a primary result of an autoimmune response against pancreatic $\beta$-cells. In contrast, hallmarks of type 2 diabetes (T2D) are peripheral insulin resistance and pancreatic $\beta$-cell failure during the later course of the disease [164].

Diabetes induces micro- and macroangiopathy. The main cause of morbidity and mortality in diabetic patients are cardiovascular complications [175]. Numerous clinical trials indicate diabetes as a major risk factor for myocardial

Christian Riehle

riehle.christian@mh-hannover.de

1 Department of Cardiology and Angiology, Hannover Medical School, Carl-Neuberg-Str. 1, Hannover 30625, Germany infarction. Similarly, diabetes increases the risk of future heart failure up to fivefold [66, 104, 105, 109, 137]. However, the high prevalence of heart failure in diabetic patients is not explained by concomitant hypertension and coronary artery disease. Over four decades ago, Rubler and colleagues reported autopsy data from diabetic patients with left ventricular (LV) dilatation in the absence of any obvious aetiology for heart failure [169]. Later reports confirmed the initial observation $[89,161]$, resulting in the concept of "diabetic cardiomyopathy" (DCM). DCM is mainly characterized by diastolic dysfunction in the absence of systolic dysfunction (heart failure with preserved ejection fraction, HFpEF) [125] and increased fibrosis in the absence of hypertension or coronary artery disease. The pathomechanisms underlying the development of DCM are multifactorial and incompletely understood. Consequently, no treatment to prevent or reverse the underlying molecular changes exists at this time [133].

Diabetes has adverse effects on the different cell types of the heart, including endothelial cells [63], fibroblasts [170] and cardiomyocytes. Various small and large animal models of T1D and T2D have been generated to study the impact of diabetes on the heart. These models are based on genetic manipulations, dietary interventions, and treatment with pancreatic toxins, which mimic many aspects of diabetes and DCM. In the present review, we will focus on studies 
performed on diabetic patients and rodent models. We will explore mechanisms, which are mainly present in cardiomyocytes and underlie the pathogenesis of DCM. Before these mechanisms will be discussed in detail, a brief introduction of the most commonly used animal models of T1D and T2D including their strengths and limitations of their use is warranted.

\section{Animal models}

Rodents, especially mice and rats, are powerful tools to study the mechanisms involved in the development of DCM. The human, mouse, and rat genomes have nearly the same size, each containing about 30,000 protein-coding genes, with about $99 \%$ of the genes encoded in the mouse genome having a homologue in humans [82, 142]. In addition to these genomic similarities, further advantages of rodent models are the short breeding cycle and the availability of a variety of genetically engineered gain-of-function and lossof-function models. The main characteristics of commonly used rodent models to study various aspects of DCM in comparison with findings from T1D and T2D patients are summarized in the Table 1, and will be discussed in detail below.

Streptozotocin (STZ) is a glucosamine-nitrosourea compound, which is toxic to pancreatic $\beta$-cells. Following intraperitoneal injection, STZ is transported into pancreatic $\beta$-cells by the glucose transporter 2 (GLUT2) based on its structural similarity to glucose, which results in necrosis and subsequent loss of insulin production [23]. STZ models are used to study both T1D and T2D. High-dose STZ protocols are primarily used to study T1D. Owing to the low penetrance of T2D development with high fat diet (HFD) chow feeding, more recent models have taken advantage of the clinical presentation of late stage T2D and $\beta$-cell destruction by adding in very low dose of STZ [11, 132, 144, 160, 218]. Another model of T1D is the OVE26 mouse, which overexpresses the $\mathrm{Ca}^{2+}$-binding protein calmodulin in pancreatic $\beta$-cells, resulting in pancreatic $\beta$-cell damage. Non-obese diabetic (NOD) mice develop T1D as a result of leukocyte infiltrate of the pancreatic islets, causing insulitis, and $\beta$-cell failure [131]. T1D Akita mice (Ins $2^{\text {Akita+/- }}$ ) exhibit a spontaneous mutation in the Insulin 2 gene, which facilitates misfolding of the insulin protein, endoplasmic reticulum (ER) stress and ultimately $\beta$-cell failure [227]. Although each of these models accurately reflects the insulin deficient nature of T1D, there are some limitations of which the most noteworthy is that they do not adequately capture the autoimmune contribution to the development of T1D in human patients [71, 155].

Commonly used transgenic models of obesity, insulin resistance and T2D are ob/ob [76] and db/db [40] mice, which are based on leptin deficiency or resistance, respectively. Similarly, Zucker fatty (ZF) rats develop obesity as a consequence of non-functional leptin receptors [154]. Zucker diabetic fatty (ZDF) rats were generated by inbreeding ZF rats with high serum glucose levels [51]. Goto-Kakizaki (GK) rats are an inbred strain derived from Wistar rats that spontaneously develop T2D [81]. Mice with adipose tissue-specific overexpression of sterol regulatory element-binding protein-1c (SREBP-1c) develop insulin resistance and elevated plasma triglyceride levels [183]. To avoid potential perturbations based on altered leptin concentrations and signalling, a variety of studies feed rodent models a HFD with increased caloric intake to induce obesity, insulin resistance, and T2D, which will be discussed in detail below.

In addition to these more direct models of diabetes, transgenic models that replicate aspects of DCM have been generated. For example, mice with cardiomyocyte-specific overexpression of the transcription factor peroxisome proliferator activated receptor $\alpha$ driven by the $\alpha$ myosin heavy chain gene promoter (MHC-PPAR $\alpha$ ) exhibit increased cardiac fatty acid oxidation (FAO) and a phenotype similar to DCM. The investigation of this models helps to explore mechanisms by which perturbed cardiac substrate oxidation impairs contractile function without systemic metabolic alterations that are associated with diabetes [72, 73]. Cardiomyocyte-selective insulin receptor knockout (CIRKO) mice are used to study the effect of decreased insulin signalling in cardiomyocytes without causing systemic metabolic disturbances [14]. The following sections and Fig. 1 summarize the main mechanisms that have been proposed to explain the increased risk of heart failure observed in T1D and T2D. The hypotheses generated are based on studies conducted on either animal models or diabetic patients.

\section{Animal studies with high caloric diets}

Numerous studies use dietary treatments to induce obesity, insulin resistance, and T2D in rodents and large animal models [189]. The term "Western" diet is commonly used for diets with a high total fat and sucrose content, which allows mimicking pathologies that have been associated with the "Western" human dietary pattern. In contrast, rodent HFD chow typically contains a variable amount of fat and a variable amount of added cholesterol [94]. Importantly, rodents usually eat any kind of fruit or grain from plants when living in their natural habitat. "Western" diet and HFD chow, which is typically used for laboratory experiments, may contain a fat content of up to $60 \%$. In comparison, the increase in fat intake in rodent models is proportionally higher compared to humans consuming "Western" diets.

HFD feeding with a relatively low fat content (45\% calories from fat) is not associated with contractile dysfunction following a short feeding duration in mice; however, systolic 


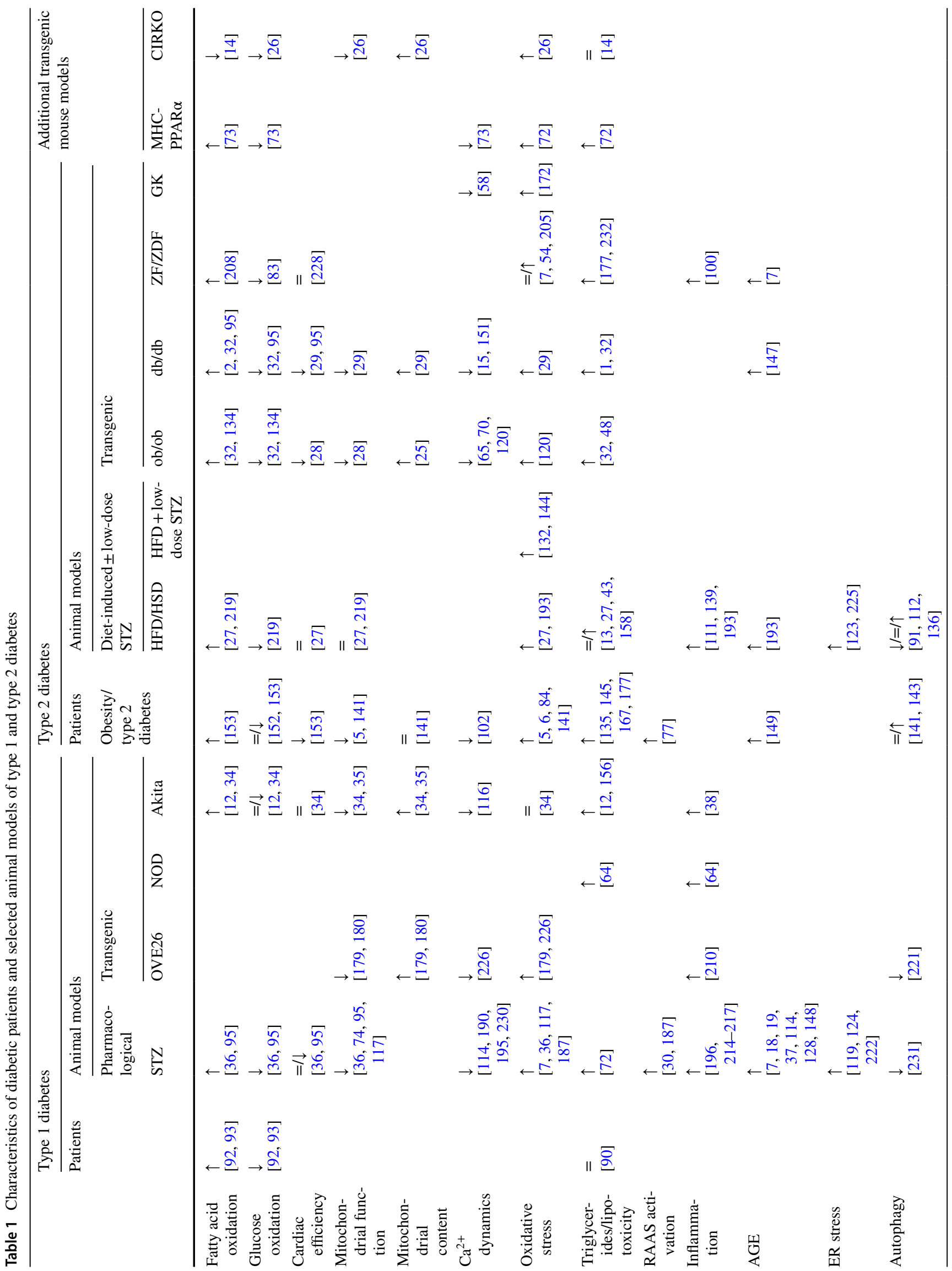




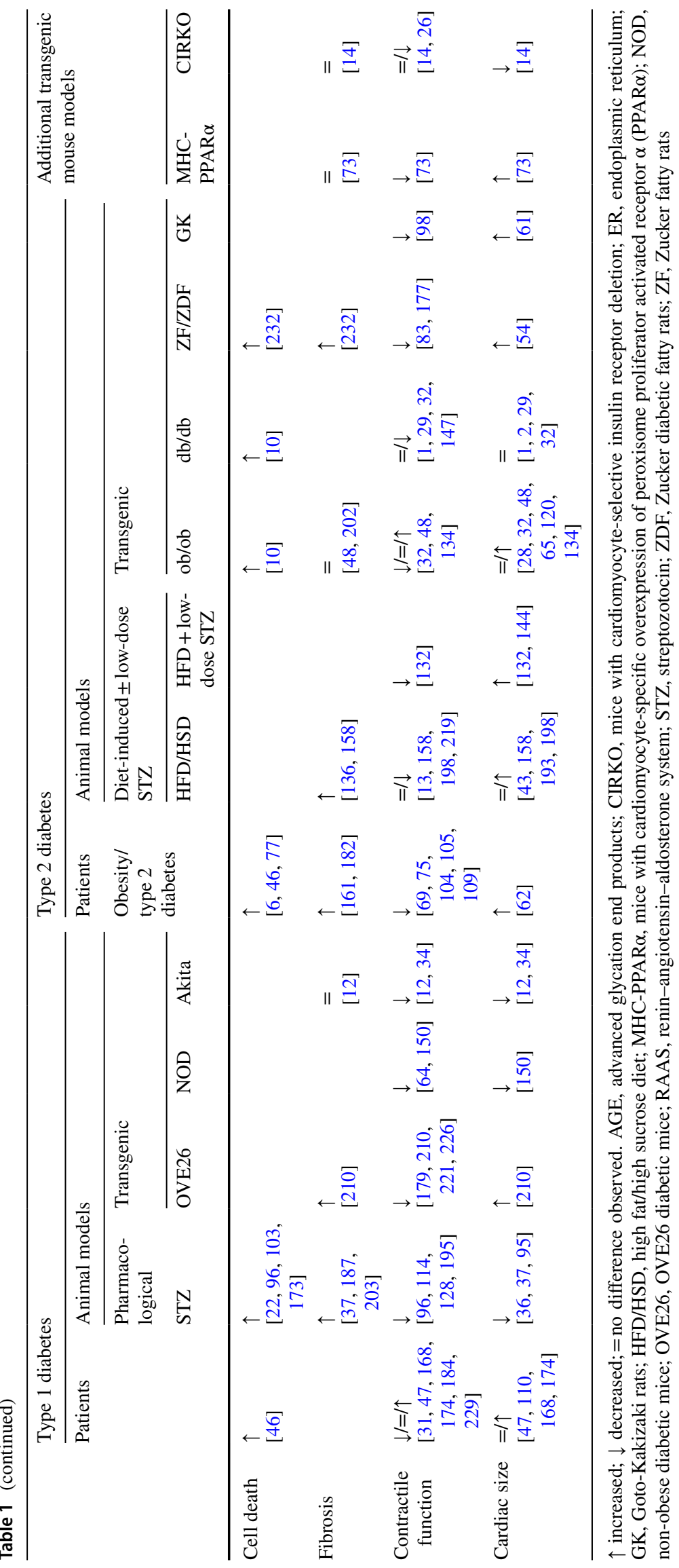




\section{DIABETES}

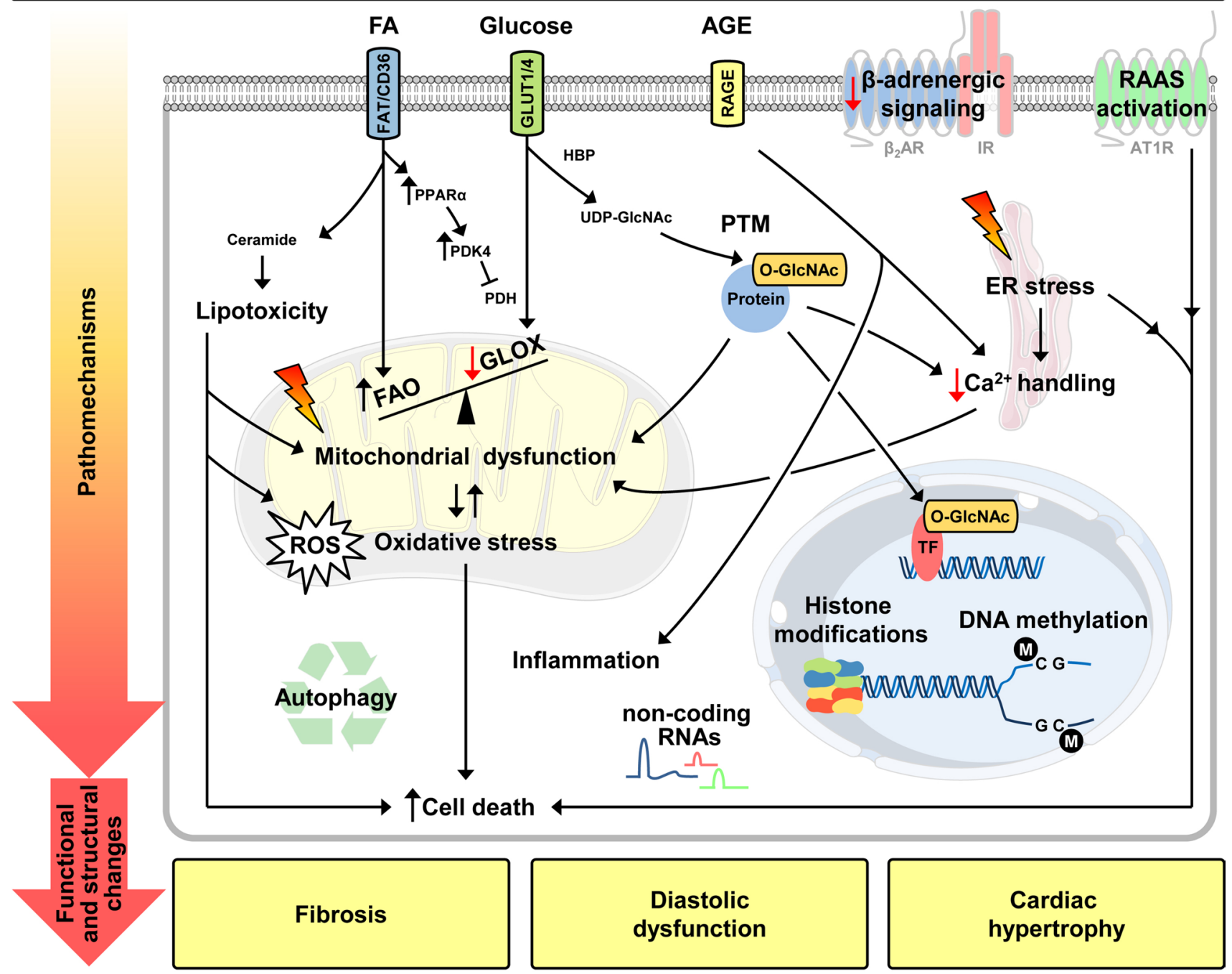

DIABETIC CARDIOMYOPATHY

Fig. 1 Pathomechanisms and clinical features of diabetic cardiomyopathy. $\uparrow$ increased/ $\downarrow$ decreased relative to normal conditions; AGE, advanced glycation end products; AT1R, angiotensin II receptor type 1; ER, endoplasmic reticulum; FAO, fatty acid (FA) oxidation; FAT/ CD36, fatty acid translocase; GLOX, glucose oxidation; HBP, hexosamine biosynthetic pathway; IR, insulin receptor; PDH, pyruvate

dysfunction develops after a prolonged duration of 20 weeks [198]. In contrast, HFD feeding of mice with $60 \%$ fat content contributes to systolic dysfunction after only 10 weeks of feeding and increases mortality [13], which suggests potential toxic effects for high caloric diets with a relatively high fat content. Similarly, exposure to "Western" diet (36\% fat content and $36 \%$ sugar content) leads to solely diastolic dysfunction, while systolic function is preserved after a total duration of 8 months [158]. Other important parameters that could provide an explanation for the different phenotypes dehydrogenase; PDK4, pyruvate dehydrogenase kinase 4; PPAR $\alpha$, peroxisome proliferator activated receptor $\alpha$; PTM, posttranslational modification; RAAS, renin-angiotensin-aldosterone system; RAGE, receptor for advanced glycation end products; ROS, reactive oxygen species; TF, transcription factor; UDP-GlcNAc, uridine diphosphate$N$-acetylglucosamine; $\beta_{2} \mathrm{AR}, \beta_{2}$-adrenergic receptor

observed are the duration of the dietary treatment and the genetic background of the species used [211].

An additional mechanism is a potential biphasic response of cardiac insulin signalling, even though not directly proven across these studies. Cardiac insulin signalling is preserved in T2D humans and rodent models following short-term HFD feeding [55, 219]. However, prolonged HFD feeding in animal models impairs Akt activation and forkhead box O-1 (FOXO1) transcription factor phosphorylation [13], which results in persistent FOXO1 nuclear localization 
and activation. The FOXO1-mediated adverse effects are multifactorial, including induction of autophagy, atrophy, and MHC isoform switching. The adverse consequences of persistent FOXO1 activation are supported by attenuated systolic dysfunction following long-term HFD feeding of mice with genetic deletion of FOXO1 [13]. Further experimental evidence is provided by transgenic animals with cardiomyocyte-specific deletion of IRS1 and IRS2, which exhibit severe heart failure $[157,166]$. This effect is ameliorated by the deletion of FOXO1 [157]. The potential biphasic response of insulin signalling is important to consider in the design of future studies. Posttranslational modification of FoxO1 also mediates cardiac collagen and protein metabolism as reported in the context of ischemic heart failure [107].

Several studies subjected rodents to high caloric diets in addition to low-dose STZ treatment [11, 132, 144, 160, 218] to induce $\beta$-cell dysfunction and insulinopenia, which are long-term complications of T2D. To objective of these studies is to overcome the potential low penetrance of diabetes development following HFD feeding in rodents. Similar to studies using HFD, the additional treatment with STZ promoted oxidative stress, cardiac hypertrophy and contractile dysfunction in diabetic mice [132, 144].

\section{Mechanisms contributing to myocardial dysfunction in diabetic patients and rodent models of T1D and T2D}

\section{Altered substrate metabolism}

Diabetes is characterized by increased FAO and decreased glucose oxidation (GLOX, Figs. 1, 2) in the heart as described for T1D [92, 93] and T2D patients [152, 153], and several rodent models (summarized in the Table 1). Multiple mechanisms mediate the shift in substrate oxidation. The earliest defects are impaired translocation and abundance of glucose transporter 4 (GLUT4), as observed in a rodent model of HFD-induced obesity and insulin resistance [219]. These data imply impaired myocardial glucose utilization for the initial increase in FAO (Randle phenomenon [159]), even before any change in serum concentrations of free fatty acids and triglycerides. Glucose uptake and cellular membrane GLUT4 expression are decreased in heart tissue from T2D patients, while insulin receptor (IR) mediated signalling is increased [55]. An independent mechanism, which may increase fatty acid uptake in diabetic hearts, is enhanced fatty acid translocase (FAT/CD36) transport to the plasma membrane [57]. Under diabetic conditions, increased circulating concentrations of fatty acids increase the activity of the transcription factor PPAR $\alpha$ [24]. PPAR $\alpha$ drives the expression of genes involved in fatty acid uptake, transport, and oxidation [165]. In addition, PPAR $\alpha$ induces the expression of pyruvate dehydrogenase kinase 4 (PDK4), thereby decreasing pyruvate dehydrogenase (PDH) activity and further suppressing GLOX [32, 219]. Importantly, hearts from MHC-PPAR $\alpha$ mice are characterized by increased FAO and a metabolic phenotype similar to that found in DCM [73, 87].

ATP production from fatty acid substrates is less efficient than glucose-based ATP production (ATP generated $/ \mathrm{O}_{2}$ consumed). Increased FAO rates in diabetic hearts enhance myocardial oxygen consumption $\left(\mathrm{mVO}_{2}\right)$. However, contractile function does not increase and cardiac efficiency (cardiac work $/ \mathrm{mVO}_{2}$ ) decreases. Studies in ob/ob and $\mathrm{db} / \mathrm{db}$ mice indicate that mitochondrial uncoupling and increased reactive oxygen species (ROS) levels parallel the increase in FAO $[28,29]$. The increase in ROS might be a consequence of an imbalance between a dysfunction of the mitochondrial electron transport chain and the increased amount of reducing equivalents generated by increased FAO. ROS have a very short half-life and are considered to cause cellular damage in close proximity to their origin, which implies mitochondria as a primary target of ROS [33]. ROS activate uncoupling proteins (UCPs) [67] that enable protons to bypass the ATP synthase embedded in the inner mitochondrial membrane, resulting in mitochondrial uncoupling (decreased coupling of mitochondrial ATP production to $\mathrm{mVO}_{2}$ ). Subsequently, FAO increases and cardiac efficiency is further impaired. Similar to T2D animal models, obese young women exhibit insulin resistance, increased $\mathrm{mVO}_{2}$ and FAO [153]. Importantly, fatty acid-mediated mitochondrial uncoupling, increased ROS levels and decreased cardiac efficiency are not present in T1D Akita mice [34], which is in contrast to T2D ob/ob and db/db mice [29, 120]. Thus, varied mechanisms might be responsible for the altered myocardial substrate utilization in the different types of diabetes. The hypothesis has been raised that ROSmediated mitochondrial uncoupling may not be attributable to hyperglycaemia alone and may be a potential consequence of insulin resistance and T2D. This is supported by recent studies in CIRKO hearts, which exhibit increased oxidative stress and mitochondrial uncoupling under normoglycaemic conditions [26].

\section{Mitochondrial dysfunction}

Mitochondrial dysfunction is a key feature of DCM and is observed in cardiac tissue from diabetic patients and models of T1D and T2D (see Table 1). Based on the mechanistic insight gained from rodent studies, the mechanisms for decreased mitochondrial oxidative capacity [5, 26-29, 34-36, 74, 95, 117, 179, 180, 219] include altered mitochondrial ultrastructure $[25,26,29,179,180]$, proteomic remodelling $[35,88,180,200]$, and oxidative damage of 


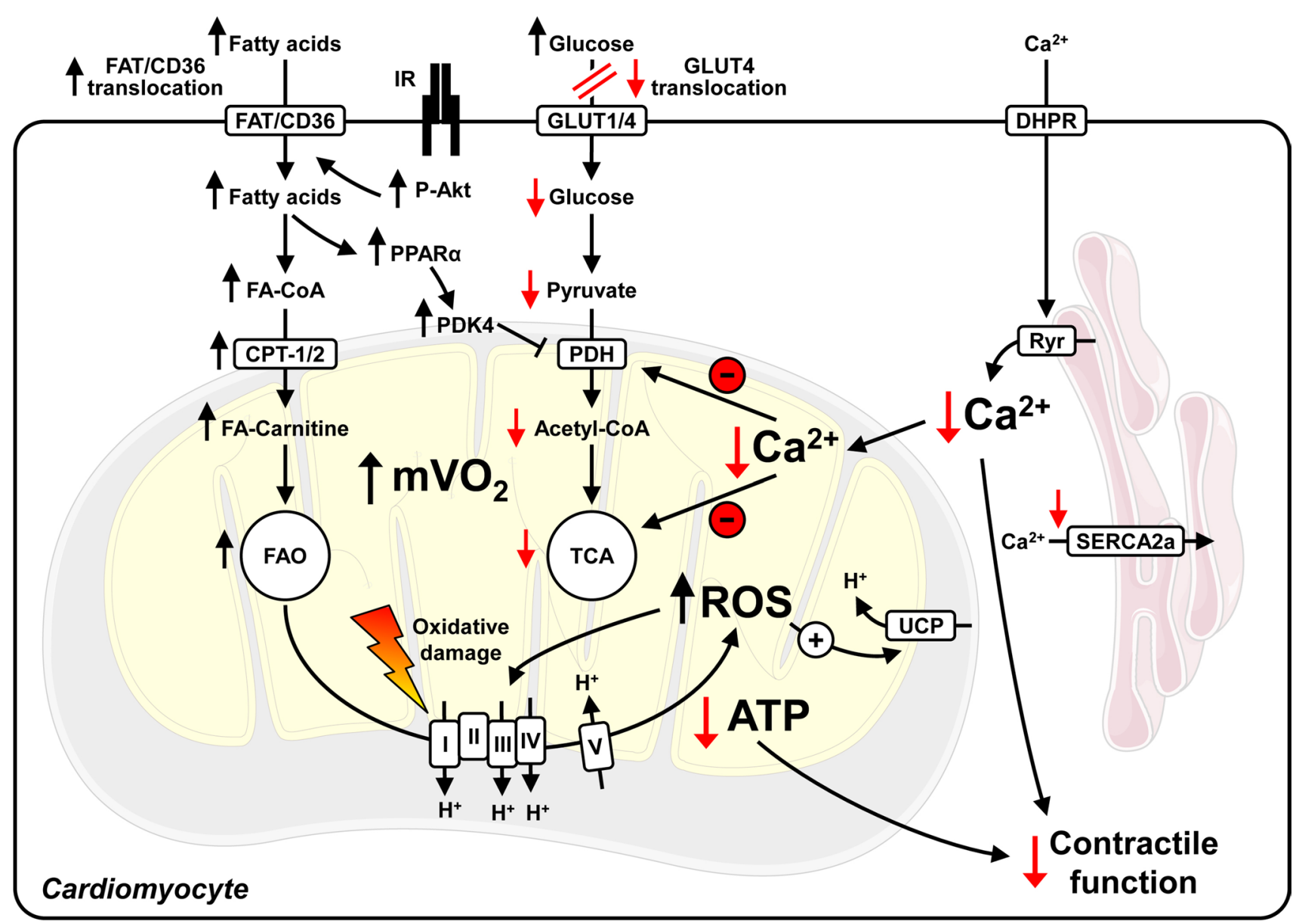

Fig. 2 Mitochondrial uncoupling and perturbed $\mathrm{Ca}^{2+}$ dynamics in cardiomyocytes of type 2 diabetic hearts. Hyperinsulinemia activates insulin receptors (IR) and Akt, contributing to increased fatty acid translocase (FAT/CD36) transport to the plasma membrane, increased fatty acid (FA) uptake and fatty acid oxidation (FAO). Impaired GLUT4 expression and translocation attenuate glucose uptake and utilization, which further increases FAO and myocardial oxygen consumption $\left(\mathrm{mVO}_{2}\right)$. Increased FAO stimulates the generation of reactive oxygen species (ROS), which may induce damage to proteins involved in oxidative phosphorylation and may activate uncoupling proteins (UCPs). Increased mitochondrial uncoupling enhances $\mathrm{mVO}_{2}$ and $\mathrm{FAO}$, and decreases mitochondrial ATP production. As the increase in $\mathrm{mVO}_{2}$ is not paralleled by increased ATP production and contractility, cardiac efficiency (cardiac work $/ \mathrm{mVO}_{2}$ ) decreases.

proteins and mitochondrial DNA [206]. Additional mechanisms for mitochondrial dysfunction comprise perturbed mitochondrial $\mathrm{Ca}^{2+}$ dynamics, mitochondrial uncoupling in $\mathrm{T} 2 \mathrm{D}$ and decreased cardiac insulin signalling in T1D, which are described in detail in the corresponding sections of this review. Compelling data for mitochondrial dysfunction in T2D patients have been provided by a series of studies by Anderson and colleagues. These studies utilized right atrial cardiac tissue, which exhibit mitochondrial dysfunction, increased oxidative stress, increased $\mathrm{H}_{2} \mathrm{O}_{2}$ emission, and increased sensitivity to $\mathrm{Ca}^{2+}$-induced opening of the
Perturbed intracellular $\mathrm{Ca}^{2+}$ handling (reduced sarcoplasmic reticulum $\mathrm{Ca}^{2+}$ release by ryanodine receptors (Ryr) and impaired reuptake by SERCA2a) reduce peak cytosolic $\mathrm{Ca}^{2+}$ levels, which may further decrease contractility and intramitochondrial $\mathrm{Ca}^{2+}$ levels. This limits the activity of mitochondrial enzymes and further compromises contractile function. Note that mitochondrial uncoupling, increased ROS and decreased cardiac efficiency are not observed in rodent models of type 1 diabetes. I-V, mitochondrial electron transport chain complexes I-V; CoA, Coenzyme A; CPT, carnitine palmitoyltransferase; DHPR, dihydropyridine receptor; PDK4, pyruvate dehydrogenase kinase 4; PPAR $\alpha$, peroxisome proliferator activated receptor $\alpha$; TCA, tricarboxylic acid cycle. $\uparrow$ increased $/ \downarrow$ decreased relative to normal conditions

mitochondrial permeability transition pore (mPTP) $[5,6]$. Recently, Jelenik and colleagues showed decreased mitochondrial coupling and efficiency in ventricular tissue from patients with impaired insulin sensitivity [101]. Importantly, mitochondrial capacity is greater in ventricular compared to atrial tissue samples in humans, which provides a rationale to study mitochondrial function preferably in ventricular tissue [118]. Maximum respiration capacity is impaired in isolated mitochondria from patients with non-alcoholic steatohepatitis (NASH) and hepatic insulin resistance. This provides evidence for mitochondrial dysfunction under 
conditions of insulin resistance even before the onset of diabetes [113].

\section{Impaired $\mathrm{Ca}^{2+}$ handling}

$\mathrm{Ca}^{2+}$ enters cardiomyocytes through voltage-dependent L-type $\mathrm{Ca}^{2+}$ channels (dihydropyridine receptor, DHPR) contributing to $\mathrm{Ca}^{2+}$ release from the sarcoplasmic reticulum by ryanodine receptors (Ryr) and contraction in systole. Intracellular $\mathrm{Ca}^{2+}$ concentrations decrease to diastolic levels following $\mathrm{Ca}^{2+}$ transport into the sarcoplasmic reticulum via SERCA2a and into the extracellular environment via the sarcolemmal $\mathrm{Na}^{+} / \mathrm{Ca}^{2+}$ exchanger (NCX). In addition to these widely studied mechanisms of $\mathrm{Ca}^{2+}$ handling more recent evidence supports that regulation of store-operated $\mathrm{Ca}^{2+}$ entry (SOCE) may also be important in the development of DCM, specifically via post-translational regulation of stromal interaction molecule 1 (STIM1) [233]. Intramitochondrial $\mathrm{Ca}^{2+}$ concentrations change during the contraction cycle [99], which promotes the activity of mitochondrial enzymes, i.e. PDH, isocitrate dehydrogenase and $\alpha$-ketoglutarate dehydrogenase $[60,146] . \mathrm{Ca}^{2+}$ handling is perturbed in T1D animal models; for example, following STZ treatment [190, 195, 230]. In T2D db/db mice, sarcoplasmic reticulum $\mathrm{Ca}^{2+}$ load is decreased, $\mathrm{Ca}^{2+}$ leakage from the sarcoplasmic reticulum is increased, and rates of $\mathrm{Ca}^{2+}$ decay are reduced $[15,151]$. Similarly, ob/ob mice exhibit impaired mitochondrial $\mathrm{Ca}^{2+}$ handling and decreased rates of intracellular $\mathrm{Ca}^{2+}$ release following electrical stimulation $[65,70]$. Cardiac fibres from T2D patients show decreased myofilament function as a consequence of impaired $\mathrm{Ca}^{2+}$ sensitivity and support the findings from rodent models [102]. Together, these studies indicate that perturbed $\mathrm{Ca}^{2+}$ handling accelerates the development of contractile dysfunction in T1D and T2D (Figs. 1 and 2).

\section{Oxidative stress}

Oxidative stress plays an essential role in the development of DCM, as described for humans $[5,6,84,141]$ and rodent models of T1D and T2D (summarized in the Table 1). Oxidative stress can result from increased levels of ROS, which is caused by either increased mitochondrial ROS generation or decreased efficiency of ROS scavengers, i.e. glutathione peroxidase (GPX), catalase, and manganese superoxide dismutase (MnSOD). Oxidative stress regulates several adverse mechanisms, including protein oxidation, generation of lipid peroxides, and formation of reactive nitrogen species from nitric oxide, which contributes to intracellular nitrosylation, such as protein tyrosine nitration [199]. Evidence for increased oxidative stress is provided by a study that utilized cardiac tissue from T2D patients, in which increased emission of mitochondrial $\mathrm{H}_{2} \mathrm{O}_{2}$ and increased abundance of 3-nitrotyrosine- and 4-hydroxynonenal (HNE)-modified proteins were observed [6]. Furthermore, overexpression of MnSOD or catalase attenuates the onset of mitochondrial dysfunction and impaired cardiomyocyte contractility in T1D OVE26 mice [179, 226].

\section{Lipotoxicity}

The uptake of lipid intermediates is increased in DCM. Intracardiomyocellular accumulation of toxic lipid metabolites accelerates myocyte death and contractile dysfunction. This is supported by several studies that utilized transgenic mouse models with increased cardiomyocyte fatty acid uptake, i.e. overexpression of fatty acid transport protein [44], long-chain acyl-CoA synthetase 1 (ACS) [45] and lipoprotein lipase with a cell-attachment glycosylphosphatidylinositol anchor, which precipitates lipotoxic cardiomyopathy, even in the absence of diabetes [224]. The proposed mechanisms have been reviewed in detail recently [213], and include increased ROS generation, changes in the ER membrane composition resulting in ER stress, increased apoptosis as a consequence of increased de novo ceramide biosynthesis, and remodelling of the mitochondrial membrane. A recent study using ACS transgenic mice revealed a novel mechanism for lipotoxic cardiomyopathy, in which posttranslational modifications of mitochondrial fusion and fission proteins increase mitochondrial fission [197]. Importantly, while numerous studies describe cardiac accumulation of triglycerides in diabetic patients [135, 145, 167, 177] and genetic rodent models of diabetes [1, 32, 48, 177, 232], triglycerides represent a marker for toxic lipid metabolite accumulation and lipotoxicity, as opposed to directly causing harmful effects [213].

\section{Renin-angiotensin-aldosterone system (RAAS) activation}

RAAS hyperactivation contributes to cardiac remodelling. RAAS inhibitors (angiotensin-converting enzyme (ACE) inhibitors, angiotensin (AT) receptor blockers and aldosterone receptor antagonists) are well-established standard treatments for chronic heart failure. The activity of the RAAS is increased under diabetic conditions [53]. Similarly, in vitro studies in neonatal rat ventricular myocytes (NRVM) identified high glucose levels as stimulators for intracellular AT II synthesis [186]. AT II receptor type 1 (AT1R) density and synthesis are increased in T1D hearts, and the increase in fibrosis is partially inhibited following treatment with ACE inhibitors and AT receptor blockers [30, 187, 214]. Together, these studies suggest that RAAS activation adversely affects cardiac structure in DCM. 


\section{Inflammation}

Studies using rodent models of T1D and T2D identified a critical role for increased myocardial inflammation in the progression of DCM. Hearts from T1D mice and rats show increased leukocyte infiltration, increased levels of pro-inflammatory cytokines (TNF $\alpha$ and IL-1 $\beta$ ), increased expression of vascular cell adhesion molecule- 1 and intercellular adhesion molecule-1, and decreased activity of the collagen degrading matrix metalloproteinase (MMP), which increases inflammation and fibrosis [196, 214, 217]. Similar data were obtained from HFD-fed and T2D rodents $[100,111,139]$. The detrimental effects caused by increased inflammation are further supported by the beneficial outcomes of a variety of interventions, which decrease inflammation in the hearts of diabetic rodents, i.e. TNF $\alpha$ antagonism [217], transgenic activation of the kallikrein-kinin system [196], AT receptor antagonist treatment [214], and pharmacological inhibition of p38 MAPK [215] or interleukin converting enzyme [216].

\section{Advanced glycation end products (AGE)}

Under hyperglycaemic conditions, AGE are formed both intra- and extracellularly via the Maillard reaction. AGE are a heterogeneous group of compounds that are formed following non-enzymatic binding of sugar derivatives to proteins, lipids and nucleic acids, which impairs the physiological function of the molecules bound [21, 185]. For example, AGE are formed on SERCA2a and Ryr, which perturbs $\mathrm{Ca}^{2+}$ dynamics $[18,19]$. Furthermore, AGE crosslink collagen molecules, contributing to increased fibrosis and contractile dysfunction [148]. In addition, AGE bind to their cognate receptor, receptor for advanced glycation end products (RAGE), which is located on the cellular membrane. One mechanism for RAGE-mediated heart failure is activation of NF- $\mathrm{KB}$ signalling, which increases $\beta$-MHC expression, as evidenced by attenuated contractile dysfunction and $\beta$-MHC expression in $\mathrm{db} / \mathrm{db}$ mice following blockage of RAGE signalling [147]. Similar effects are present in T1D and T2D rats following treatment with the antioxidant dehydroepiandrosterone (DHEA), thus indicating a critical role for oxidative stress in the activation of RAGE-mediated pathways under diabetic conditions [7]. Additional RAGEmediated mechanisms are increased ROS production and pro-inflammatory signalling [21]. Transgenic overexpression of the methylglyoxal-metabolizing enzyme glyoxalase-1 (GLO1) in mice decreases methylglyoxal-AGE levels and attenuates the onset of heart failure following myocardial infarction. These mice exhibit increased vascular density and decreased cardiomyocyte apoptosis compared to wildtype controls, which is paralleled by increased recruitment of c-kit ${ }^{+}$progenitor cells and their incorporation into the vasculature [20]. Repeated percutaneous infusions of cardiac mesenchymal cells in mice with ischemic cardiomyopathy significantly improve contractile function compared to a single dose treatment, which suggests that multiple infusions are required for the full therapeutic potential of cell therapy [86]. In STZ-induced T1D rats, treatment with the crosslink breaker ALT-711 decreases cardiac AGE levels, restores collagen solubility, and diminishes diabetes-induced gene expression [37]. Similarly, siRNA-mediated knockdown of RAGE attenuates LV dysfunction in T1D mice [128].

\section{ER stress}

The main physiological function of the ER is $\mathrm{Ca}^{2+}$ storage and folding of proteins. Accumulation of unfolded proteins inside the ER lumen causes a stress response, termed ER stress, which can result in apoptotic cell death in rodent models of T1D and T2D [115, 222]. ER stress also activates the unfolded protein response (UPR), which attenuates this effect. The main task of the UPR is to maintain cellular integrity by decreasing protein synthesis, degrading misfolded proteins, and increasing the synthesis of chaperones, which facilitate protein folding. Numerous studies have suggested a causative role for oxidative stress in the induction of ER stress under diabetic conditions [119, 124, 222].

\section{Autophagy}

Autophagy is an evolutionarily conserved process that recycles long-lived proteins and organelles to maintain cellular homeostasis. Depending on the extent of autophagy and its duration, autophagy can have both beneficial and detrimental effects. Perturbed autophagy is associated with the pathogenesis of infectious diseases, cancer, obesity, and various disease conditions of the heart, including ischemia/reperfusion injury, cardiac hypertrophy and DCM $[112,163]$. Studies have provided opposing results in the context of DCM.

Autophagy is decreased in rodent models of T1D [221, 231]. The proposed mechanisms comprise repression of AMPK and activation of mTOR under hyperglycaemic conditions. In contrast, autophagy is increased in some animal models of diet-induced obesity and T2D, but the evidence for this has not been consistent $[91,112,136]$. The underlying mechanisms for the differences in autophagy in T1D relative to $\mathrm{T} 2 \mathrm{D}$ and the various models investigated need further investigation.

While T1D is associated with insulinopenia and impaired cardiac insulin signalling, proximal insulin signalling is preserved in T2D [55, 219]. Preserved insulin/mTOR signalling could be predicted to suppress autophagy in T2D, which is in contrast to some of the prior investigations. Therefore, differences in insulin signalling cannot fully explain the differences in autophagy when comparing the different types of 
diabetes. This also suggests that multiple mechanisms regulate autophagy in DCM that are, at least in part, independent of cardiac insulin signalling. It is also important to note that autophagy is a highly dynamic process and the differences detected might be attributed to experimental limitations in determining autophagic flux. Thus, additional research is warranted to gain further mechanistic insight and elucidate the impact of autophagy in DCM.

\section{Posttranslational modification (PTM)}

PTMs can alter the activity of proteins. Metabolic-driven PTMs are particularly important in diabetes, i.e. acetylation and O-GlcNAcylation. Sirtuins (SIRTs) are defined as $\mathrm{NAD}^{+}$-dependent class III histone deacetylases that deacetylate target proteins involved in FAO, glucose metabolism, and mitochondrial energetics. SIRTs are differentially regulated in models of heart failure and in animal models of T1D and T2D. For example, cardiac SIRT3 expression is decreased in HFD-fed mice, which increases acetylation of mitochondrial $\beta$-oxidation enzymes and increases FAO [4]. Expression of SIRT isoforms is mediated by dietary interventions and pharmacological treatment; for example, treatment with the anti-oxidant resveratrol increases the expression of SIRT1 [207], implying SIRTs as potential pharmacological targets.

Increased protein O-GlcNAcylation has adverse effects in DCM as recently reviewed [212]. Glucose is converted to fructose-6-phosphate in the first steps of glycolysis, which enters the hexosamine biosynthesis pathway (HBP). Under physiological conditions, about $5 \%$ of total glucose is metabolized in the HBP, which is further increased under diabetic conditions. Multiple pathways provide intermediates for the HBP, including metabolic pathways for the biosynthesis and degradation of amino acids, fatty acids, and nucleotides, which directly links the availability of nutrients to the substrate supply of the HBP. The end product of the HPB, uridine diphosphate-N-acetylglucosamine (UDP-GlcNAc), is transferred to serine or threonine residues of target proteins by the enzyme O-GlcNAc transferase (OGT), a process termed O-GlcNAcylation. In contrast to non-enzymatic AGE formation, O-GlcNAcylation is a reversible posttranslational modification, with UDP-GlcNAc removal catalysed by O-GlcNAcase (OGA). Multiple nuclear, cytoplasmic, and mitochondrial proteins are targets for O-GlcNAc modification. O-GlcNAcylation also plays a central role in $\mathrm{Ca}^{2+}$ homeostasis, as evidenced by the modification of transcription factors regulating the expression of SERCA2a [52] and the sarcoplasmic reticulum protein STIM1, thereby attenuating SOCE and $\mathrm{Ca}^{2+}$ signalling [233]. O-GlcNAcylation of $\mathrm{Ca}^{2+} /$ calmodulin-dependent protein kinase 2 (CAMKII) impairs $\mathrm{Ca}^{2+}$ handling and increases the risk of cardiac arrhythmia in diabetes [68].
O-GlcNAcylation directly impairs mitochondrial capacity. Proteomic studies identified 86 mitochondrial proteins as O-GlcNAc targets, with target proteins involved in major metabolic pathways, including the FAO and tricarboxylic acid (TCA) cycles [129]. UDP-GlcNAc is transported from the cytosol into mitochondria by the pyrimidine nucleotide carrier (PNC1) and cardiac mitochondria express both OGA and OGT [9]. OGT expression is increased in mitochondria from T1D rat hearts and modulation of OGT or OGA activity affects mitochondrial capacity [9]. These data indicate that cardiac mitochondria express the required machinery for O-GlcNAc modification which, in turn, regulates mitochondrial capacity. Together, O-GlcNAcylation provides an exciting new area of research, linking the availability of nutrients to cardiac energetics and contractile dysfunction, which may accelerate the onset of heart failure in diabetes.

\section{Epigenetics}

Epigenetics is a rapidly expanding area of research and refer to a heritable modification of gene expression without alterations in DNA sequences. The modifications include noncoding RNAs (i.e. microRNAs and long-noncoding RNAs), DNA methylation, and histone modifications. Epigenetics are important during embryogenesis and play a central role during development and the pathogenesis of various disease conditions, including DCM. In addition to the transgenerational nature of epigenetics, these modifications can also be part of transcriptional regulation and may be regulated by altered metabolic flux directly associated with hyperglycaemia and other metabolic changes seen in diabetes [56].

\section{miRNAs and IncRNAs}

MicroRNAs (miRNAs or miRs) are short, single-stranded, non-coding RNA molecules consisting of about 22 nucleotides. The majority of miRNAs are encoded within the introns of protein-coding and non-coding genes. miRNAs are evolutionarily conserved and regulate gene expression at the post-transcriptional level. The mechanisms of miRNA-based gene regulation include binding of miRNAs to mRNAs for later degradation or repression of translation. Each miRNA can target multiple mRNAs, which provides the possibility to a single miRNA to orchestrate an entire pattern of gene expression. miRNAs play an important role in the regulation of cellular energy homeostasis, metabolism, and pathogenesis of numerous diseases, including diabetes. For example, miRNAs-103/107 are up-regulated in livers from ob/ob and diet-induced obese mice, and silencing of miRNAs-103/107 improves glucose homeostasis and insulin sensitivity [194]. Numerous miRNAs regulate cardiac fibrosis and hypertrophy [191]. For example, miRNA-21 augments pathological cardiac 
remodelling by stimulating MAP kinase signalling in fibroblasts [192]. Similarly, miRNAs are differentially regulated in diabetic hearts $[85,126,178]$. One example is miRNA-223, which is upregulated in LV biopsies from T2D patients and regulates GLUT4 expression and glucose uptake [126]. As previously reviewed, miRNA expression is altered in rodent models of T1D and T2D [85, 176]. One example of this has been observed in T2D ZDF rats, in which dysregulated miRNA-29 expression is correlated with cardiac structural damage [8]. Furthermore, differences in miRNA profiles regulate the hyperglycaemic memory in DCM. miRNA array analysis performed on LV tissue from STZ-induced T1D mice indicated dysregulation of 316 out of 1008 miRNAs. Following normalization of blood glucose levels by insulin treatment, the expression of 268 miRNAs remained significantly altered, thus suggesting a contribution of miRNAs to glycaemic memory. Ingenuity pathway analysis indicates that dysregulated miRNAs are implicated in myocardial signalling networks regulating autophagy, hypertrophic growth, oxidative stress, fibrosis, and heart failure, all of which are characteristics of DCM [39].

Long-noncoding RNAs (lncRNAs) are transcripts that are longer than 200 nucleotides, which can repress or enhance gene expression [204]. Similarly to miRNAs, IncRNAs contribute to the development of DCM [121, 127]. Circulating IncRNAs predict LV diastolic function and remodelling in patients with T2D [59]. The rapidly growing field of noncoding RNA research will likely provide additional insights into non-coding RNAs and the development of DCM.

\section{DNA methylation}

DNA methylation involves the transfer of a methyl group to cytosine of $\mathrm{CpG}$ dinucleotides in promoter regions to form 5-methylcytosine, which typically represses gene transcription. The expression of genes associated with the development of DCM is regulated by the methylation status of $\mathrm{CpG}$ islands, for example SERCA2a [106]. Another example is the expression of liver $\mathrm{X}$ receptor- $\alpha(\mathrm{LXR} \alpha)$, which is increased in cardiac tissue from T1D rats and regulates the expression of fatty acid metabolism genes. Bisulfite genomic sequencing showed significant differences in the methylation status of the CpG island at the LXR $\alpha$ promoter region [42]. Oxidative stress mediates DNA methylation in T1D hearts, which inhibits DNA synthesis and increases p53-dependent cell death signalling. Oxidative stress-mediated mechanisms involve methylation of the gene encoding the p53-inducible

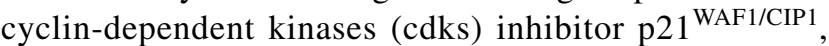
which inhibits DNA synthesis and prevents the replication of damaged DNA [140]. These data link epigenetic DNA modifications to the pathogenesis of DCM.

\section{Histone modifications}

Histones package DNA into structural units called nucleosomes, which are the first level of chromatin organization. Each nucleosome consists of an octameric histone core wrapped in 147 base pairs of DNA. Histone tails are modified by a variety PTMs, including methylation, phosphorylation, ubiquitylation, and acetylation, which regulates gene expression. The acetylation status of histones is a major epigenetic mechanism that is mediated by histone acetyltransferases (HATs) and histone deacetylases (HDACs). HDACs play a critical role in embryonic development, cardiac hypertrophy and heart failure. There is emerging evidence that HDACs are involved in the development of DCM, as indicated by attenuated interstitial fibrosis and apoptosis following HDAC inhibition in T1D mice [41, 223]. Furthermore, histones $\mathrm{H} 2 \mathrm{~A}, \mathrm{H} 2 \mathrm{~B}$ and $\mathrm{H} 4$ are modified by O-GlcNAcylation [171], thereby directly linking nutrient availability to gene expression.

\section{Decreased $\beta$-adrenergic signalling}

Signalling pathways transduced by the IR and $\beta$-adrenergic receptors ( $\beta \mathrm{ARs})$ mediate divergent and overlapping pathways in the heart. Recent studies revealed a critical crosstalk between insulin and $\beta$-adrenergic signalling, which impairs cardiac contractility in T2D [78, 209]. $\beta$ AR signalling is increased in heart failure. Studies in humans and animal models show that cardiac insulin signalling is preserved or increased in diet-induced obesity, T2D, and heart failure [55, 181, 219]. Pressure overload-induced hypertrophy and heart failure result in hyperinsulinemia and systemic insulin resistance, which accelerate adverse LV remodelling. This effect is attenuated by systemic insulin deficiency or genetic reduction of cardiac IR-transduced signalling by heterozygous cardiomyocyte-specific deletion of the IR [181]. Importantly, large clinical studies have shown that strict insulin treatment of T2D patients increases mortality, despite a reduced incidence of microvascular complications, such as nephropathy and neuropathy [3].

$\beta_{1} \mathrm{AR}$ is the predominant $\beta \mathrm{AR}$ receptor subtype expressed in cardiomyocytes, which couples to stimulatory $\mathrm{G}$ protein, $\mathrm{G}_{\mathrm{s}}$. In contrast, $\beta_{2}$ ARs bind to both $\mathrm{G}_{\mathrm{s}}$ and inhibitory $\mathrm{G}$ protein, $G_{i}$. $G_{s}$-mediated signalling induces cyclic adenosine $3^{\prime}, 5^{\prime}$-monophosphate (cAMP)-dependent activation of protein kinase A (PKA) and phosphorylation of phospholamban, which increases myocyte contractility [220]. IR and $\beta$ ARs share $\mathrm{G}_{\mathrm{i}}[188]$ and $\mathrm{G}$-protein receptor kinase 2 (GRK2) [49, 50, 201] as common downstream effectors, which serve as nodes linking these two signalling pathways. A functional membrane complex consisting of the IR and $\beta_{2} \mathrm{AR}$ was also recently discovered [78, 79]. Insulin stimulates translocation of GRK2 to the IR, which contributes to 
GRK2-mediated phosphorylation of the $\beta_{2} \mathrm{AR}$ and enhanced $\mathrm{G}_{\mathrm{i}}$-mediated signalling. Insulin increases the expression of phosphodiesterase 4D (PDE4D), which antagonizes cAMP activity and decreases PKA phosphorylation, thereby promoting contractile dysfunction [209]. Induction of PDE4D and contractile dysfunction are attenuated in HFD-fed mice following pharmacological inhibition of GRK2 with paroxetine, a FDA-approved selective serotonin reuptake inhibitor. Similar data were obtained following treatment with the $\beta_{2}$ AR blocker Carvedilol [209]. This mechanism provides a potential explanation for the harmful effects of intensive insulin treatment observed in T2D patients, suggesting GRK2 and $\beta_{2} \mathrm{AR}$ as potential promising pharmacological targets for the treatment of cardiomyopathy in T2D.

\section{Increased cell death}

Increased apoptotic and necrotic cardiomyocyte death is commonly detected in patients $[6,46,77]$ and rodent models of T1D and T2D [10, 22, 96, 103, 173, 232]. Right atrial appendages from T1D and T2D patients subjected to elective coronary artery bypass surgery exhibit increased rates of apoptosis and necrosis, which are exacerbated following simulated ischemia/reperfusion [46]. The proposed mechanisms triggering cell death are increased caspase activation [46], ROS production [96], ER stress [173], activation of death-receptor- and mitochondrion-dependent pro-apoptotic pathways [22], RAAS activation [103], and leptin deficiency, as indicated by decreased apoptosis in ob/ob mice following leptin treatment [10].

\section{Structural and functional consequences}

\section{Increased fibrosis}

In DCM, increased collagen accumulation is observed in perivascular loci, between myofibers, and as replacement fibrosis [161]. Similarly, type III, but not type I or IV collagen deposition, is increased in myocardial biopsies from T2D patients without prior history of hypertension and coronary artery disease [182]. Increased myocardial fibrosis may contribute to diastolic dysfunction in DCM. Serum concentrations of the carboxy-terminal propeptide of procollagen type I (PIP), a marker of myocardial fibrosis, are increased in T2D patients with overt diastolic function, in which lower mitral and tricuspid E/A ratios were detected [97]. Fibrosis is also increased in some animal models of T1D [37, 187, 203, 210] and T2D [138, 232]. The mechanisms responsible for increased fibrosis and connective tissue content include AGE-mediated remodelling of the extracellular matrix (ECM), increased transforming growth factor $\beta$ (TGF $\beta$ )-mediated signalling, increased connective tissue growth factor (CTGF) expression, and decreased expression of MMP-2, resulting in attenuated extracellular matrix degradation [203].

\section{Diastolic dysfunction}

A key clinical feature of DCM is diastolic dysfunction (see Fig. 3) with preserved ejection fraction (HFpEF), which may precede the later onset of systolic dysfunction (heart failure with reduced ejection fraction, HFrEF). As discussed in the
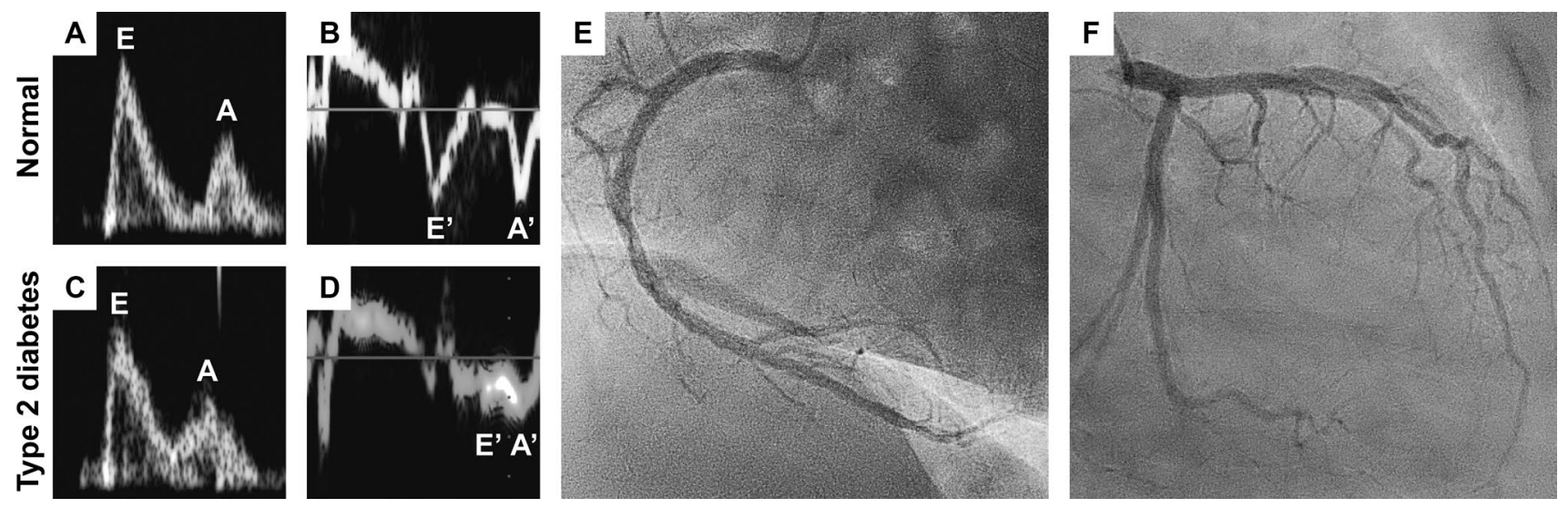

Fig. 3 Diastolic dysfunction in the absence of coronary artery disease in a patient with type 2 diabetes. a Preserved diastolic function in a normal subject as indicated by the $E / A$ wave ratio ( $E$ : peak velocity blood flow in early diastole, $A$ : peak velocity blood flow in late diastole caused by atrial contraction), b $E^{\prime} / A^{\prime}$ wave ratio $\left(E^{\prime}\right.$ : peak mitral annular velocity during early diastolic filling, $A^{\prime}$ : peak mitral annular velocity during late diastolic filling caused by atrial contraction).
Diastolic dysfunction in a patient with type 2 diabetes as indicated by c an abnormal high ("pseudonormal") $E / A$ wave ratio and $E / E$, wave ratio as calculated from the values presented in panels (c) and (d). Images were adjusted to the same scales. Coronary angiogram of the e right coronary artery system and $\mathbf{f}$ left main coronary artery system from the same patient presented in panels (c/d) indicating no concomitant coronary artery disease 
previous sections, various mechanisms contribute to diastolic dysfunction, including AGE, increased fibrosis, and perturbed $\mathrm{Ca}^{2+}$ homeostasis. Diastolic dysfunction may be present in as many as $60-75 \%$ of diabetic patients, and is even more apparent under conditions of superimposed myocardial ischemic heart disease or hypertension [16, 122, 184]. Furthermore, LV diastolic dysfunction may be present under conditions of insulin resistance even before the onset of T2D, independently of age, blood pressure, and body mass index [75]. After exclusion of patients with coronary artery disease, systolic dysfunction is detected in $24 \%$ of T2D patients, as determined by strain analyses and peak systolic velocity measurements [69]. While studies have reported diastolic dysfunction in T1D patients [31, 174, 229], reports on systolic function in T1D are inconsistent, with some studies indicating preserved [168, 174] or increased systolic function [47]. The different results for studies with T1D and T2D patients may be a consequence of the selection of patients and the causative treatment of T1D patients with exogenous insulin, which may normalize the systemic milieu.

Cardiac contractile function has also been extensively investigated in numerous animal models of T1D and T2D. Both diastolic and systolic dysfunction has been observed in some of the models investigated (see Table 1). Importantly, the majority of studies with animal models did not use blood glucose level-normalizing treatments, which further emphasizes the impact of hyperglycaemia and metabolic disturbances on the development of contractile dysfunction.

\section{Cardiac hypertrophy}

Another clinical feature of DCM is LV hypertrophy, especially in T2D. While data from the Framingham Heart Study and the Framingham Offspring Study show an association between diabetes, LV wall thickness and mass in women, but not in men [80], the Strong Heart Study conducted in Native Americans reports increased LV mass and wall thickness in both men and women [62]. Data from the Strong Heart Study suggest that LV hypertrophy increases the risk of future heart failure, especially in the context of co-existing hypertension [17]. LV hypertrophy is not observed in patients with impaired fasting glucose [162], indicating that LV hypertrophy might result from hyperglycaemia and other metabolic changes associated with longer existing diabetes. Proposed mechanisms contributing to LV hypertrophy are hyperactivation of the insulin signalling cascade in obese and T2D patients $[55,108]$ and increased levels of circulating pro-inflammatory cytokines. In contrast, most studies do not report myocardial hypertrophy in T1D patients [47, 168, 174] and animal models of T1D (see Table 1). Similarly, genetic deletion of the insulin receptor decreases cardiac size [14]. These studies further highlight the impact of insulin as a growth factor and hyperinsulinemia as a pathomechanism for LV hypertrophy in obesity and T2D.

\section{Summary and conclusions}

Various pathomechanisms contribute to the pathogenesis of DCM. Rodent models are essential tools to decipher these mechanisms and mimic perturbations observed in T1D and T2D patients. Despite specific limitations of the models generated, transgenic mice are indispensable for mechanistic studies that provide mechanistic insight into the pathogenesis of DCM. Different treatment strategies have been tested in patients with diabetes mellitus and heart failure. These studies indicate that diabetic patients benefit from standard heart failure treatment. However, previous studies also suggest that selected diabetes mellitus treatment regimens may have adverse effects on cardiac function and increase heart failure hospitalization [130,164]. These observations also emphasize the need for additional studies to gain further mechanistic insight. Recent advancements in genome editing will result in the generation of novel models in the near future. These models will aid our understanding of the pathophysiology of DCM and hopefully accelerate the development of new therapeutic strategies for this rapidly expanding form of heart disease.

Acknowledgements This work was supported by the German Research Foundation, Clinical Research Unit (KFO) 311. Figures were produced using templates from Servier Medical Art (www.servier.com). The authors thank Dr. Jan-Thorben Sieweke for his help in preparing the figures.

\section{Compliance with ethical standrads}

Conflict of interest The authors declare that they have no conflict of interest.

Open Access This article is distributed under the terms of the Creative Commons Attribution 4.0 International License (http://creativeco mmons.org/licenses/by/4.0/), which permits unrestricted use, distribution, and reproduction in any medium, provided you give appropriate credit to the original author(s) and the source, provide a link to the Creative Commons license, and indicate if changes were made.

\section{References}

1. Aasum E, Belke DD, Severson DL, Riemersma RA, Cooper M, Andreassen M, Larsen TS (2002) Cardiac function and metabolism in Type 2 diabetic mice after treatment with BM 17.0744, a novel PPAR-alpha activator. Am J Physiol Heart Circ Physiol 283:H949-957. https://doi.org/10.1152/ajpheart.00226.2001

2. Aasum E, Hafstad AD, Severson DL, Larsen TS (2003) Agedependent changes in metabolism, contractile function, and 
ischemic sensitivity in hearts from $\mathrm{db} / \mathrm{db}$ mice. Diabetes $52: 434$ 441. https://doi.org/10.2337/diabetes.52.2.434

3. Action to Control Cardiovascular Risk in Diabetes Study G, Gerstein HC, Miller ME, Byington RP, Goff DC Jr, Bigger JT, Buse JB, Cushman WC, Genuth S, Ismail-Beigi F, Grimm RH Jr, Probstfield JL, Simons-Morton DG, Friedewald WT (2008) Effects of intensive glucose lowering in type 2 diabetes. N Engl J Med 358:2545-2559. https://doi.org/10.1056/NEJMoa0802743

4. Alrob OA, Sankaralingam S, Ma C, Wagg CS, Fillmore N, Jaswal JS, Sack MN, Lehner R, Gupta MP, Michelakis ED, Padwal RS, Johnstone DE, Sharma AM, Lopaschuk GD (2014) Obesityinduced lysine acetylation increases cardiac fatty acid oxidation and impairs insulin signalling. Cardiovasc Res 103:485-497. https://doi.org/10.1093/cvr/cvu156

5. Anderson EJ, Kypson AP, Rodriguez E, Anderson CA, Lehr EJ, Neufer PD (2009) Substrate-specific derangements in mitochondrial metabolism and redox balance in the atrium of the type 2 diabetic human heart. J Am Coll Cardiol 54:1891-1898. https:// doi.org/10.1016/j.jacc.2009.07.031

6. Anderson EJ, Rodriguez E, Anderson CA, Thayne K, Chitwood WR, Kypson AP (2011) Increased propensity for cell death in diabetic human heart is mediated by mitochondrial-dependent pathways. Am J Physiol Heart Circ Physiol 300:H118-124. https ://doi.org/10.1152/ajpheart.00932.2010

7. Aragno M, Mastrocola R, Medana C, Catalano MG, Vercellinatto I, Danni O, Boccuzzi G (2006) Oxidative stress-dependent impairment of cardiac-specific transcription factors in experimental diabetes. Endocrinology 147:5967-5974. https://doi. org/10.1210/en.2006-0728

8. Arnold N, Koppula PR, Gul R, Luck C, Pulakat L (2014) Regulation of cardiac expression of the diabetic marker microRNA miR-29. PLoS One 9:e103284. https://doi.org/10.1371/journ al.pone. 0103284

9. Banerjee PS, Ma J, Hart GW (2015) Diabetes-associated dysregulation of O-GlcNAcylation in rat cardiac mitochondria. Proc Natl Acad Sci USA 112:6050-6055. https://doi.org/10.1073/ pnas. 1424017112

10. Barouch LA, Gao D, Chen L, Miller KL, Xu W, Phan AC, Kittleson MM, Minhas KM, Berkowitz DE, Wei C, Hare JM (2006) Cardiac myocyte apoptosis is associated with increased DNA damage and decreased survival in murine models of obesity. Circ Res 98:119-124. https://doi.org/10.1161/01.RES.0000199348 $.10580 .1 \mathrm{~d}$

11. Barriere DA, Noll C, Roussy G, Lizotte F, Kessai A, Kirby K, Belleville K, Beaudet N, Longpre JM, Carpentier AC, Geraldes P, Sarret P (2018) Combination of high-fat/high-fructose diet and low-dose streptozotocin to model long-term type-2 diabetes complications. Sci Rep 8:424. https://doi.org/10.1038/s4159 8-017-18896-5

12. Basu R, Oudit GY, Wang X, Zhang L, Ussher JR, Lopaschuk GD, Kassiri Z (2009) Type 1 diabetic cardiomyopathy in the Akita (Ins2WT/C96Y) mouse model is characterized by lipotoxicity and diastolic dysfunction with preserved systolic function. Am J Physiol Heart Circ Physiol 297:H2096-2108. https://doi. org/10.1152/ajpheart.00452.2009

13. Battiprolu PK, Hojayev B, Jiang N, Wang ZV, Luo X, Iglewski M, Shelton JM, Gerard RD, Rothermel BA, Gillette TG, Lavandero S, Hill JA (2012) Metabolic stress-induced activation of FoxO1 triggers diabetic cardiomyopathy in mice. J Clin Invest 122:1109-1118. https://doi.org/10.1172/JCI60329

14. Belke DD, Betuing S, Tuttle MJ, Graveleau C, Young ME, Pham M, Zhang D, Cooksey RC, McClain DA, Litwin SE, Taegtmeyer H, Severson D, Kahn CR, Abel ED (2002) Insulin signaling coordinately regulates cardiac size, metabolism, and contractile protein isoform expression. J Clin Invest 109:629-639. https://doi. org/10.1172/JCI13946
15. Belke DD, Swanson EA, Dillmann WH (2004) Decreased sarcoplasmic reticulum activity and contractility in diabetic $\mathrm{db} / \mathrm{db}$ mouse heart. Diabetes 53:3201-3208. https://doi.org/10.2337/ diabetes.53.12.3201

16. Bell DS (2003) Diabetic cardiomyopathy. Diabetes Care 26:2949-2951. https://doi.org/10.2337/diacare.26.10.2949

17. Bella JN, Devereux RB, Roman MJ, Palmieri V, Liu JE, Paranicas M, Welty TK, Lee ET, Fabsitz RR, Howard BV (2001) Separate and joint effects of systemic hypertension and diabetes mellitus on left ventricular structure and function in American Indians (the Strong Heart Study). Am J Cardiol 87:1260-1265. https://doi.org/10.1016/S0002-9149(01)01516-8

18. Bidasee KR, Nallani K, Yu Y, Cocklin RR, Zhang Y, Wang M, Dincer UD, Besch HR Jr (2003) Chronic diabetes increases advanced glycation end products on cardiac ryanodine receptors/calcium-release channels. Diabetes 52:1825-1836. https:// doi.org/10.2337/diabetes.52.7.1825

19. Bidasee KR, Zhang Y, Shao CH, Wang M, Patel KP, Dincer UD, Besch HR Jr (2004) Diabetes increases formation of advanced glycation end products on Sarco(endo)plasmic reticulum Ca2 +-ATPase. Diabetes 53:463-473. https://doi.org/10.2337/ diabetes.53.2.463

20. Blackburn NJR, Vulesevic B, McNeill B, Cimenci CE, Ahmadi A, Gonzalez-Gomez M, Ostojic A, Zhong Z, Brownlee M, Beisswenger PJ, Milne RW, Suuronen EJ (2017) Methylglyoxalderived advanced glycation end products contribute to negative cardiac remodeling and dysfunction post-myocardial infarction. Basic Res Cardiol 112:57. https://doi.org/10.1007/s0039 5-017-0646-x

21. Bodiga VL, Eda SR, Bodiga S (2014) Advanced glycation end products: role in pathology of diabetic cardiomyopathy. Heart Fail Rev 19:49-63. https://doi.org/10.1007/s10741-013-9374-y

22. Bojunga J, Nowak D, Mitrou PS, Hoelzer D, Zeuzem S, Chow KU (2004) Antioxidative treatment prevents activation of death-receptor- and mitochondrion-dependent apoptosis in the hearts of diabetic rats. Diabetologia 47:2072-2080. https://doi. org/10.1007/s00125-004-1572-7

23. Bonnevie-Nielsen V, Steffes MW, Lernmark A (1981) A major loss in islet mass and B-cell function precedes hyperglycemia in mice given multiple low doses of streptozotocin. Diabetes 30:424-429. https://doi.org/10.2337/diab.30.5.424

24. Boudina S, Abel ED (2007) Diabetic cardiomyopathy revisited. Circulation 115:3213-3223. https://doi.org/10.1161/CIRCU LATIONAHA.106.679597

25. Boudina S, Abel ED (2006) Mitochondrial uncoupling: a key contributor to reduced cardiac efficiency in diabetes. Physiol (Bethesda) 21:250-258. https://doi.org/10.1152/physiol.00008 .2006

26. Boudina S, Bugger H, Sena S, O’Neill BT, Zaha VG, Ilkun O, Wright JJ, Mazumder PK, Palfreyman E, Tidwell TJ, Theobald $\mathrm{H}$, Khalimonchuk O, Wayment B, Sheng X, Rodnick KJ, Centini R, Chen D, Litwin SE, Weimer BE, Abel ED (2009) Contribution of impaired myocardial insulin signaling to mitochondrial dysfunction and oxidative stress in the heart. Circulation 119:12721283. https://doi.org/10.1161/CIRCULATIONAHA.108.792101

27. Boudina S, Han YH, Pei S, Tidwell TJ, Henrie B, Tuinei J, Olsen C, Sena S, Abel ED (2012) UCP3 regulates cardiac efficiency and mitochondrial coupling in high fat-fed mice but not in leptindeficient mice. Diabetes 61:3260-3269. https://doi.org/10.2337/ db12-0063

28. Boudina S, Sena S, O’Neill BT, Tathireddy P, Young ME, Abel ED (2005) Reduced mitochondrial oxidative capacity and increased mitochondrial uncoupling impair myocardial energetics in obesity. Circulation 112:2686-2695. https://doi. org/10.1161/CIRCULATIONAHA.105.554360 
29. Boudina S, Sena S, Theobald H, Sheng X, Wright JJ, Hu XX, Aziz S, Johnson JI, Bugger H, Zaha VG, Abel ED (2007) Mitochondrial energetics in the heart in obesity-related diabetes: direct evidence for increased uncoupled respiration and activation of uncoupling proteins. Diabetes 56:2457-2466. https://doi. org/10.2337/db07-0481

30. Brown L, Wall D, Marchant C, Sernia C (1997) Tissue-specific changes in angiotensin II receptors in streptozotocin-diabetic rats. J Endocrinol 154:355-362. https://doi.org/10.1677/joe.0.15403 55

31. Brunvand L, Fugelseth D, Stensaeth KH, Dahl-Jorgensen K, Margeirsdottir HD (2016) Early reduced myocardial diastolic function in children and adolescents with type 1 diabetes mellitus a population-based study. BMC Cardiovasc Disord 16:103. https ://doi.org/10.1186/s12872-016-0288-1

32. Buchanan J, Mazumder PK, Hu P, Chakrabarti G, Roberts MW, Yun UJ, Cooksey RC, Litwin SE, Abel ED (2005) Reduced cardiac efficiency and altered substrate metabolism precedes the onset of hyperglycemia and contractile dysfunction in two mouse models of insulin resistance and obesity. Endocrinology 146:5341-5349. https://doi.org/10.1210/en.2005-0938

33. Bugger H, Abel ED (2010) Mitochondria in the diabetic heart. Cardiovasc Res 88:229-240. https://doi.org/10.1093/cvr/cvq239

34. Bugger H, Boudina S, Hu XX, Tuinei J, Zaha VG, Theobald HA, Yun UJ, McQueen AP, Wayment B, Litwin SE, Abel ED (2008) Type 1 diabetic akita mouse hearts are insulin sensitive but manifest structurally abnormal mitochondria that remain coupled despite increased uncoupling protein 3. Diabetes 57:2924-2932. https://doi.org/10.2337/db08-0079

35. Bugger H, Chen D, Riehle C, Soto J, Theobald HA, Hu XX, Ganesan B, Weimer BC, Abel ED (2009) Tissue-specific remodeling of the mitochondrial proteome in type 1 diabetic akita mice. Diabetes 58:1986-1997. https://doi.org/10.2337/db09-0259

36. Bugger H, Riehle C, Jaishy B, Wende AR, Tuinei J, Chen D, Soto J, Pires KM, Boudina S, Theobald HA, Luptak I, Wayment B, Wang X, Litwin SE, Weimer BC, Abel ED (2012) Genetic loss of insulin receptors worsens cardiac efficiency in diabetes. J Mol Cell Cardiol 52:1019-1026. https://doi.org/10.1016/j.yjmcc 2012.02.001

37. Candido R, Forbes JM, Thomas MC, Thallas V, Dean RG, Burns WC, Tikellis C, Ritchie RH, Twigg SM, Cooper ME, Burrell LM (2003) A breaker of advanced glycation end products attenuates diabetes-induced myocardial structural changes. Circ Res 92:785-792. https://doi.org/10.1161/01.RES.0000065620.39919 .20

38. Chavali V, Tyagi SC, Mishra PK (2014) Differential expression of dicer, miRNAs, and inflammatory markers in diabetic Ins $2 \pm$ Akita hearts. Cell Biochem Biophys 68:25-35. https://doi. org/10.1007/s12013-013-9679-4

39. Costantino S, Paneni F, Luscher TF, Cosentino F (2016) MicroRNA profiling unveils hyperglycaemic memory in the diabetic heart. Eur Heart J 37:572-576. https://doi.org/10.1093/eurheartj/ ehv599

40. Chen H, Charlat O, Tartaglia LA, Woolf EA, Weng X, Ellis SJ, Lakey ND, Culpepper J, Moore KJ, Breitbart RE, Duyk GM, Tepper RI, Morgenstern JP (1996) Evidence that the diabetes gene encodes the leptin receptor: identification of a mutation in the leptin receptor gene in $\mathrm{db} / \mathrm{db}$ mice. Cell 84:491-495. https:// doi.org/10.1016/S0092-8674(00)81294-5

41. Chen Y, Du J, Zhao YT, Zhang L, Lv G, Zhuang S, Qin G, Zhao TC (2015) Histone deacetylase (HDAC) inhibition improves myocardial function and prevents cardiac remodeling in diabetic mice. Cardiovasc Diabetol 14:99. https://doi.org/10.1186/s1293 3-015-0262-8

42. Cheng Y, Liu G, Pan Q, Guo S, Yang X (2011) Elevated expression of liver $\mathrm{X}$ receptor alpha (LXRalpha) in myocardium of streptozotocin-induced diabetic rats. Inflammation 34:698-706. https://doi.org/10.1007/s10753-010-9281-5

43. Chess DJ, Khairallah RJ, O'Shea KM, Xu W, Stanley WC (2009) A high-fat diet increases adiposity but maintains mitochondrial oxidative enzymes without affecting development of heart failure with pressure overload. Am J Physiol Heart Circ Physiol 297:H1585-1593. https://doi.org/10.1152/ajpheart.00599.2009

44. Chiu HC, Kovacs A, Blanton RM, Han X, Courtois M, Weinheimer CJ, Yamada KA, Brunet S, Xu H, Nerbonne JM, Welch MJ, Fettig NM, Sharp TL, Sambandam N, Olson KM, Ory DS, Schaffer JE (2005) Transgenic expression of fatty acid transport protein 1 in the heart causes lipotoxic cardiomyopathy. Circ Res 96:225-233. https://doi.org/10.1161/01.RES.0000154079.20681 .B9

45. Chiu HC, Kovacs A, Ford DA, Hsu FF, Garcia R, Herrero P, Saffitz JE, Schaffer JE (2001) A novel mouse model of lipotoxic cardiomyopathy. J Clin Invest 107:813-822. https://doi.org/10.1172/ JCI10947

46. Chowdhry MF, Vohra HA, Galinanes M (2007) Diabetes increases apoptosis and necrosis in both ischemic and nonischemic human myocardium: role of caspases and poly-adenosine diphosphate-ribose polymerase. J Thorac Cardiovasc Surg 134:124-131, 131 e121-123. https://doi.org/10.1016/j.jtcvs .2006.12.059

47. Christiansen EH, Molgaard H, Christensen PD, Sorensen KE, Christensen CK, Mogensen CE (1998) Increased left ventricular systolic function in insulin dependent diabetic patients with normal albumin excretion. Eur Heart J 19:1735-1739. https:// doi.org/10.1053/euhj.1998.1090

48. Christoffersen C, Bollano E, Lindegaard ML, Bartels ED, Goetze JP, Andersen CB, Nielsen LB (2003) Cardiac lipid accumulation associated with diastolic dysfunction in obese mice. Endocrinology 144:3483-3490. https://doi.org/10.1210/en.2003-0242

49. Ciccarelli M, Chuprun JK, Rengo G, Gao E, Wei Z, Peroutka RJ, Gold JI, Gumpert A, Chen M, Otis NJ, Dorn GW 2nd, Trimarco B, Iaccarino G, Koch WJ (2011) G protein-coupled receptor kinase 2 activity impairs cardiac glucose uptake and promotes insulin resistance after myocardial ischemia. Circulation 123:1953-1962. https://doi.org/10.1161/CIRCULATIO NAHA.110.988642

50. Cipolletta E, Campanile A, Santulli G, Sanzari E, Leosco D, Campiglia P, Trimarco B, Iaccarino G (2009) The G protein coupled receptor kinase 2 plays an essential role in beta-adrenergic receptor-induced insulin resistance. Cardiovasc Res 84:407-415. https://doi.org/10.1093/cvr/cvp252

51. Clark JB, Palmer CJ, Shaw WN (1983) The diabetic Zucker fatty rat. Proc Soc Exp Biol Med 173:68-75. https://doi. org/10.3181/00379727-173-41611

52. Clark RJ, McDonough PM, Swanson E, Trost SU, Suzuki M, Fukuda M, Dillmann WH (2003) Diabetes and the accompanying hyperglycemia impairs cardiomyocyte calcium cycling through increased nuclear O-GlcNAcylation. J Biol Chem 278:44230 44237. https://doi.org/10.1074/jbc.M303810200

53. Connelly KA, Boyle AJ, Kelly DJ (2007) Angiotensin II and the cardiac complications of diabetes mellitus. Curr Pharm Des 13:2721-2729. https://doi.org/10.2174/138161207781662984

54. Conti M, Renaud IM, Poirier B, Michel O, Belair MF, Mandet C, Bruneval P, Myara I, Chevalier J (2004) High levels of myocardial antioxidant defense in aging nondiabetic normotensive Zucker obese rats. Am J Physiol Regul Integr Comp Physiol 286:R793-800. https://doi.org/10.1152/ajpregu.00521.2002

55. Cook SA, Varela-Carver A, Mongillo M, Kleinert C, Khan MT, Leccisotti L, Strickland N, Matsui T, Das S, Rosenzweig A, Punjabi P, Camici PG (2010) Abnormal myocardial insulin signalling in type 2 diabetes and left-ventricular dysfunction. Eur Heart $\mathrm{J}$ 31:100-111. https://doi.org/10.1093/eurheartj/ehp396 
56. Cooper ME, El-Osta A (2010) Epigenetics: mechanisms and implications for diabetic complications. Circ Res 107:14031413. https://doi.org/10.1161/CIRCRESAHA.110.223552

57. Coort SL, Hasselbaink DM, Koonen DP, Willems J, Coumans WA, Chabowski A, van der Vusse GJ, Bonen A, Glatz JF, Luiken JJ (2004) Enhanced sarcolemmal FAT/CD36 content and triacylglycerol storage in cardiac myocytes from obese zucker rats. Diabetes 53:1655-1663. https://doi.org/10.2337/diabetes.53.7.1655

58. Darmellah A, Baetz D, Prunier F, Tamareille S, Rucker-Martin C, Feuvray D (2007) Enhanced activity of the myocardial $\mathrm{Na}+/ \mathrm{H}+$ exchanger contributes to left ventricular hypertrophy in the Goto-Kakizaki rat model of type 2 diabetes: critical role of Akt. Diabetologia 50:1335-1344. https://doi.org/10.1007/s0012 5-007-0628-x

59. de Gonzalo-Calvo D, Kenneweg F, Bang C, Toro R, van der Meer RW, Rijzewijk LJ, Smit JW, Lamb HJ, Llorente-Cortes V, Thum $\mathrm{T}$ (2016) Circulating long-non coding RNAs as biomarkers of left ventricular diastolic function and remodelling in patients with well-controlled type 2 diabetes. Sci Rep 6:37354. https:// doi.org/10.1038/srep37354

60. Denton RM, Randle PJ, Martin BR (1972) Stimulation by calcium ions of pyruvate dehydrogenase phosphate phosphatase. Biochem J 128:161-163. https://doi.org/10.1042/bj1280161

61. Desrois M, Sidell RJ, Gauguier D, Davey CL, Radda GK, Clarke K (2004) Gender differences in hypertrophy, insulin resistance and ischemic injury in the aging type 2 diabetic rat heart. $\mathrm{J}$ Mol Cell Cardiol 37:547-555. https://doi.org/10.1016/j.yjmcc .2004.05.014

62. Devereux RB, Roman MJ, Paranicas M, O'Grady MJ, Lee ET, Welty TK, Fabsitz RR, Robbins D, Rhoades ER, Howard BV (2000) Impact of diabetes on cardiac structure and function: the strong heart study. Circulation 101:2271-2276. https://doi. org/10.1161/01.CIR.101.19.2271

63. Di Carli MF, Janisse J, Grunberger G, Ager J (2003) Role of chronic hyperglycemia in the pathogenesis of coronary microvascular dysfunction in diabetes. J Am Coll Cardiol 41:1387-1393. https://doi.org/10.1016/S0735-1097(03)00166-9

64. Dong B, Qi D, Yang L, Huang Y, Xiao X, Tai N, Wen L, Wong FS (2012) TLR4 regulates cardiac lipid accumulation and diabetic heart disease in the nonobese diabetic mouse model of type 1 diabetes. Am J Physiol Heart Circ Physiol 303:H732-742. https ://doi.org/10.1152/ajpheart.00948.2011

65. Dong F, Zhang X, Yang X, Esberg LB, Yang H, Zhang Z, Culver B, Ren J (2006) Impaired cardiac contractile function in ventricular myocytes from leptin-deficient ob/ob obese mice. J Endocrinol 188:25-36. https://doi.org/10.1677/joe.1.06241

66. Dries DL, Sweitzer NK, Drazner MH, Stevenson LW, Gersh BJ (2001) Prognostic impact of diabetes mellitus in patients with heart failure according to the etiology of left ventricular systolic dysfunction. J Am Coll Cardiol 38:421-428. https://doi. org/10.1016/S0735-1097(01)01408-5

67. Echtay KS, Murphy MP, Smith RA, Talbot DA, Brand MD (2002) Superoxide activates mitochondrial uncoupling protein 2 from the matrix side. Studies using targeted antioxidants. J Biol Chem 277:47129-47135. https://doi.org/10.1074/jbc.M2082 62200

68. Erickson JR, Pereira L, Wang L, Han G, Ferguson A, Dao K, Copeland RJ, Despa F, Hart GW, Ripplinger CM, Bers DM (2013) Diabetic hyperglycaemia activates CaMKII and arrhythmias by O-linked glycosylation. Nature 502:372-376. https://doi. org/10.1038/nature 12537

69. Fang ZY, Schull-Meade R, Leano R, Mottram PM, Prins JB, Marwick TH (2005) Screening for heart disease in diabetic subjects. Am Heart J 149:349-354. https://doi.org/10.1016/j. ahj.2004.06.021
70. Fauconnier J, Lanner JT, Zhang SJ, Tavi P, Bruton JD, Katz A, Westerblad H (2005) Insulin and inositol 1,4,5-trisphosphate trigger abnormal cytosolic $\mathrm{Ca} 2+$ transients and reveal mitochondrial $\mathrm{Ca} 2+$ handling defects in cardiomyocytes of ob/ob mice. Diabetes 54:2375-2381. https://doi.org/10.2337/diabe tes.54.8.2375

71. Feduska JM, Tse HM (2018) The proinflammatory effects of macrophage-derived NADPH oxidase function in autoimmune diabetes. Free Radic Biol Med 125:81-89. https://doi. org/10.1016/j.freeradbiomed.2018.04.581

72. Finck BN, Han X, Courtois M, Aimond F, Nerbonne JM, Kovacs A, Gross RW, Kelly DP (2003) A critical role for PPARalphamediated lipotoxicity in the pathogenesis of diabetic cardiomyopathy: modulation by dietary fat content. Proc Natl Acad Sci USA 100:1226-1231. https://doi.org/10.1073/pnas.0336724100

73. Finck BN, Lehman JJ, Leone TC, Welch MJ, Bennett MJ, Kovacs A, Han X, Gross RW, Kozak R, Lopaschuk GD, Kelly DP (2002) The cardiac phenotype induced by PPARalpha overexpression mimics that caused by diabetes mellitus. J Clin Invest 109:121130. https://doi.org/10.1172/JCI14080

74. Flarsheim CE, Grupp IL, Matlib MA (1996) Mitochondrial dysfunction accompanies diastolic dysfunction in diabetic rat heart. Am J Physiol 271:H192-202. https://doi.org/10.1152/ajphe art.1996.271.1.H192

75. Fontes-Carvalho R, Ladeiras-Lopes R, Bettencourt P, LeiteMoreira A, Azevedo A (2015) Diastolic dysfunction in the diabetic continuum: association with insulin resistance, metabolic syndrome and type 2 diabetes. Cardiovasc Diabetol 14:4. https ://doi.org/10.1186/s12933-014-0168-x

76. Friedman JM, Halaas JL (1998) Leptin and the regulation of body weight in mammals. Nature 395:763-770. https://doi. org/10.1038/27376

77. Frustaci A, Kajstura J, Chimenti C, Jakoniuk I, Leri A, Maseri A, Nadal-Ginard B, Anversa P (2000) Myocardial cell death in human diabetes. Circ Res 87:1123-1132. https://doi. org/10.1161/01.RES.87.12.1123

78. Fu Q, Xu B, Liu Y, Parikh D, Li J, Li Y, Zhang Y, Riehle C, Zhu Y, Rawlings T, Shi Q, Clark RB, Chen X, Abel ED, Xiang YK (2014) Insulin inhibits cardiac contractility by inducing a Gibiased beta2-adrenergic signaling in hearts. Diabetes 63:26762689. https://doi.org/10.2337/db13-1763

79. Fu Q, Xu B, Parikh D, Cervantes D, Xiang YK (2015) Insulin induces IRS2-dependent and GRK2-mediated beta2AR internalization to attenuate betaAR signaling in cardiomyocytes. Cell Signal 27:707-715. https://doi.org/10.1016/j.cellsig.2014.11.018

80. Galderisi M, Anderson KM, Wilson PW, Levy D (1991) Echocardiographic evidence for the existence of a distinct diabetic cardiomyopathy (the Framingham Heart Study). Am J Cardiol 68:85-89. https://doi.org/10.1016/0002-9149(91)90716-X

81. Gauguier D, Froguel P, Parent V, Bernard C, Bihoreau MT, Portha B, James MR, Penicaud L, Lathrop M, Ktorza A (1996) Chromosomal mapping of genetic loci associated with non-insulin dependent diabetes in the GK rat. Nat Genet 12:38-43. https ://doi.org/10.1038/ng0196-38

82. Gibbs RA, Weinstock GM, Metzker ML, Muzny DM, Sodergren EJ, Scherer S, Scott G, Steffen D, Worley KC, Burch PE, Okwuonu G, Hines S, Lewis L, DeRamo C, Delgado O, Dugan-Rocha S, Miner G, Morgan M, Hawes A, Gill R, Celera Holt RA, Adams MD, Amanatides PG, Baden-Tillson H, Barnstead M, Chin S, Evans CA, Ferriera S, Fosler C, Glodek A, Gu Z, Jennings D, Kraft CL, Nguyen T, Pfannkoch CM, Sitter C, Sutton GG, Venter JC, Woodage T, Smith D, Lee HM, Gustafson E, Cahill P, Kana A, Doucette-Stamm L, Weinstock K, Fechtel K, Weiss RB, Dunn DM, Green ED, Blakesley RW, Bouffard GG, De Jong PJ, Osoegawa K, Zhu B, Marra M, Schein J, Bosdet I, Fjell C, Jones S, Krzywinski M, Mathewson 
C, Siddiqui A, Wye N, McPherson J, Zhao S, Fraser CM, Shetty J, Shatsman S, Geer K, Chen Y, Abramzon S, Nierman WC, Havlak PH, Chen R, Durbin KJ, Egan A, Ren Y, Song XZ, Li B, Liu Y, Qin X, Cawley S, Worley KC, Cooney AJ, D’Souza LM, Martin K, Wu JQ, Gonzalez-Garay ML, Jackson AR, Kalafus KJ, McLeod MP, Milosavljevic A, Virk D, Volkov A, Wheeler DA, Zhang Z, Bailey JA, Eichler EE et al (2004) Genome sequence of the Brown Norway rat yields insights into mammalian evolution. Nature 428:493-521. https://doi. org/10.1038/nature02426

83. Golfman LS, Wilson CR, Sharma S, Burgmaier M, Young ME, Guthrie PH, Van Arsdall M, Adrogue JV, Brown KK, Taegtmeyer H (2005) Activation of PPARgamma enhances myocardial glucose oxidation and improves contractile function in isolated working hearts of ZDF rats. Am J Physiol Endocrinol Metab 289:E328-336. https://doi.org/10.1152/ajpendo.00055.2005

84. Gonzalez-Vilchez F, Ayuela J, Ares M, Pi J, Castillo L, Martin-Duran R (2005) Oxidative stress and fibrosis in incipient myocardial dysfunction in type 2 diabetic patients. Int J Cardiol 101:53-58. https://doi.org/10.1016/j.ijcard.2004.03.009

85. Guo R, Nair S (2017) Role of microRNA in diabetic cardiomyopathy: from mechanism to intervention. Biochim Biophys Acta Mol Basis Dis 1863:2070-2077. https://doi.org/10.1016/j.bbadi s.2017.03.013

86. Guo Y, Wysoczynski M, Nong Y, Tomlin A, Zhu X, Gumpert AM, Nasr M, Muthusamy S, Li H, Book M, Khan A, Hong KU, Li Q, Bolli R (2017) Repeated doses of cardiac mesenchymal cells are therapeutically superior to a single dose in mice with old myocardial infarction. Basic Res Cardiol 112:18. https://doi. org/10.1007/s00395-017-0606-5

87. Hafstad AD, Khalid AM, Hagve M, Lund T, Larsen TS, Severson DL, Clarke K, Berge RK, Aasum E (2009) Cardiac peroxisome proliferator-activated receptor-alpha activation causes increased fatty acid oxidation, reducing efficiency and post-ischaemic functional loss. Cardiovasc Res 83:519-526. https://doi.org/10.1093/ $\mathrm{cvr} / \mathrm{cvp} 132$

88. Hamblin M, Friedman DB, Hill S, Caprioli RM, Smith HM, Hill MF (2007) Alterations in the diabetic myocardial proteome coupled with increased myocardial oxidative stress underlies diabetic cardiomyopathy. J Mol Cell Cardiol 42:884-895. https ://doi.org/10.1016/j.yjmcc.2006.12.018

89. Hamby RI, Zoneraich S, Sherman L (1974) Diabetic cardiomyopathy. JAMA 229:1749-1754. https://doi.org/10.1001/ jama.1974.03230510023016

90. Hammer S, Jonker JT, Lamb HJ, van der Meer RW, Zondag W, Sepers JM, de Roos A, Smit JW, Romijn JA (2008) Short-term hyperglycemic dysregulation in patients with type 1 diabetes does not change myocardial triglyceride content or myocardial function. Diabetes Care 31:1613-1614. https://doi.org/10.2337/ dc08-0513

91. He C, Bassik MC, Moresi V, Sun K, Wei Y, Zou Z, An Z, Loh J, Fisher J, Sun Q, Korsmeyer S, Packer M, May HI, Hill JA, Virgin HW, Gilpin C, Xiao G, Bassel-Duby R, Scherer PE, Levine B (2012) Exercise-induced BCL2-regulated autophagy is required for muscle glucose homeostasis. Nature 481:511-515. https:// doi.org/10.1038/nature10758

92. Herrero P, McGill J, Lesniak DS, Dence CS, Scott SW, Kisrieva-Ware Z, Gropler RJ (2008) PET detection of the impact of dobutamine on myocardial glucose metabolism in women with type 1 diabetes mellitus. J Nucl Cardiol 15:791-799. https://doi. org/10.1007/BF03007360

93. Herrero P, Peterson LR, McGill JB, Matthew S, Lesniak D, Dence C, Gropler RJ (2006) Increased myocardial fatty acid metabolism in patients with type 1 diabetes mellitus. J Am Coll Cardiol 47:598-604. https://doi.org/10.1016/j.jacc.2005.09.030
94. Hintze KJ, Benninghoff AD, Cho CE, Ward RE (2018) Modeling the western diet for preclinical investigations. Adv Nutr 9:263-271. https://doi.org/10.1093/advances/nmy002

95. How OJ, Aasum E, Severson DL, Chan WY, Essop MF, Larsen TS (2006) Increased myocardial oxygen consumption reduces cardiac efficiency in diabetic mice. Diabetes 55:466-473. https ://doi.org/10.2337/diabetes.55.02.06.db05-1164

96. Huynh K, Kiriazis H, Du XJ, Love JE, Gray SP, Jandeleit-Dahm KA, McMullen JR, Ritchie RH (2013) Targeting the upregulation of reactive oxygen species subsequent to hyperglycemia prevents type 1 diabetic cardiomyopathy in mice. Free Radic Biol Med 60:307-317. https://doi.org/10.1016/j.freeradbio med.2013.02.021

97. Ihm SH, Youn HJ, Shin DI, Jang SW, Park CS, Kim PJ, Kim HY, Chang K, Seung KB, Kim JH, Choi KB (2007) Serum carboxyterminal propeptide of type I procollagen (PIP) is a marker of diastolic dysfunction in patients with early type 2 diabetes mellitus. Int J Cardiol 122:e36-38. https://doi.org/10.1016/j.ijcar d.2007.07.057

98. Iltis I, Kober F, Desrois M, Dalmasso C, Lan C, Portha B, Cozzone PJ, Bernard M (2005) Defective myocardial blood flow and altered function of the left ventricle in type 2 diabetic rats: a noninvasive in vivo study using perfusion and cine magnetic resonance imaging. Invest Radiol 40:19-26. https://doi. org/10.1097/01.rli.0000148276.57159.55

99. Isenberg G, Han S, Schiefer A, Wendt-Gallitelli MF (1993) Changes in mitochondrial calcium concentration during the cardiac contraction cycle. Cardiovasc Res 27:1800-1809. https:// doi.org/10.1093/cvr/27.10.1800

100. Jadhav A, Tiwari S, Lee P, Ndisang JF (2013) The heme oxygenase system selectively enhances the anti-inflammatory macrophage-M2 phenotype, reduces pericardial adiposity, and ameliorated cardiac injury in diabetic cardiomyopathy in Zucker diabetic fatty rats. J Pharmacol Exp Ther 345:239-249. https:// doi.org/10.1124/jpet.112.200808

101. Jelenik T, Flogel U, Alvarez-Hernandez E, Scheiber D, Zweck E, Ding Z, Rothe M, Mastrototaro L, Kohlhaas V, Kotzka J, Knebel B, Muller-Wieland D, Moellendorf S, Godecke A, Kelm M, Westenfeld R, Roden M, Szendroedi J (2018) Insulin resistance and vulnerability to cardiac ischemia. Diabetes. https://doi. org/10.2337/db18-0449

102. Jweied EE, McKinney RD, Walker LA, Brodsky I, Geha AS, Massad MG, Buttrick PM, de Tombe PP (2005) Depressed cardiac myofilament function in human diabetes mellitus. Am J Physiol Heart Circ Physiol 289:H2478-2483. https://doi. org/10.1152/ajpheart.00638.2005

103. Kajstura J, Fiordaliso F, Andreoli AM, Li B, Chimenti S, Medow MS, Limana F, Nadal-Ginard B, Leri A, Anversa P (2001) IGF-1 overexpression inhibits the development of diabetic cardiomyopathy and angiotensin II-mediated oxidative stress. Diabetes 50:1414-1424. https://doi.org/10.2337/diabetes.50.6.1414

104. Kannel WB, Hjortland M, Castelli WP (1974) Role of diabetes in congestive heart failure: the Framingham study. Am J Cardiol 34:29-34. https://doi.org/10.1016/0002-9149(74)90089-7

105. Kannel WB, McGee DL (1979) Diabetes and cardiovascular disease. The Framingham study. JAMA 241:2035-2038. https://doi. org/10.1001/jama.1979.03290450033020

106. Kao YH, Chen YC, Cheng CC, Lee TI, Chen YJ, Chen SA (2010) Tumor necrosis factor-alpha decreases sarcoplasmic reticulum $\mathrm{Ca} 2$ +-ATPase expressions via the promoter methylation in cardiomyocytes. Crit Care Med 38:217-222. https://doi. org/10.1097/CCM.0b013e3181b4a854

107. Kappel BA, Stohr R, De Angelis L, Mavilio M, Menghini R, Federici M (2016) Posttranslational modulation of FoxO1 contributes to cardiac remodeling in post-ischemic heart failure. 
Atherosclerosis 249:148-156. https://doi.org/10.1016/j.ather osclerosis.2016.04.001

108. Karason K, Sjostrom L, Wallentin I, Peltonen M (2003) Impact of blood pressure and insulin on the relationship between body fat and left ventricular structure. Eur Heart J 24:1500-1505. https ://doi.org/10.1016/S0195-668X(03)00312-9

109. Kenchaiah S, Evans JC, Levy D, Wilson PW, Benjamin EJ, Larson MG, Kannel WB, Vasan RS (2002) Obesity and the risk of heart failure. N Engl J Med 347:305-313. https://doi. org/10.1056/NEJMoa020245

110. Kimball TR, Daniels SR, Khoury PR, Magnotti RA, Turner AM, Dolan LM (1994) Cardiovascular status in young patients with insulin-dependent diabetes mellitus. Circulation 90:357-361. https://doi.org/10.1161/01.CIR.90.1.357

111. Ko HJ, Zhang Z, Jung DY, Jun JY, Ma Z, Jones KE, Chan SY, Kim JK (2009) Nutrient stress activates inflammation and reduces glucose metabolism by suppressing AMP-activated protein kinase in the heart. Diabetes 58:2536-2546. https://doi. org/10.2337/db08-1361

112. Kobayashi S, Liang Q (2015) Autophagy and mitophagy in diabetic cardiomyopathy. Biochim Biophys Acta 1852:252-261. https://doi.org/10.1016/j.bbadis.2014.05.020

113. Koliaki C, Szendroedi J, Kaul K, Jelenik T, Nowotny P, Jankowiak F, Herder C, Carstensen M, Krausch M, Knoefel WT, Schlensak M, Roden M (2015) Adaptation of hepatic mitochondrial function in humans with non-alcoholic fatty liver is lost in steatohepatitis. Cell Metab 21:739-746. https://doi.org/10.1016/j. cmet.2015.04.004

114. Kranstuber AL, Del Rio C, Biesiadecki BJ, Hamlin RL, Ottobre J, Gyorke S, Lacombe VA (2012) Advanced glycation end product cross-link breaker attenuates diabetes-induced cardiac dysfunction by improving sarcoplasmic reticulum calcium handling. Front Physiol 3:292. https://doi.org/10.3389/fphys.2012.00292

115. Lakshmanan AP, Harima M, Suzuki K, Soetikno V, Nagata M, Nakamura T, Takahashi T, Sone H, Kawachi H, Watanabe K (2013) The hyperglycemia stimulated myocardial endoplasmic reticulum (ER) stress contributes to diabetic cardiomyopathy in the transgenic non-obese type 2 diabetic rats: a differential role of unfolded protein response (UPR) signaling proteins. Int $\mathbf{J}$ Biochem Cell Biol 45:438-447. https://doi.org/10.1016/j.bioce 1.2012.09.017

116. LaRocca TJ, Fabris F, Chen J, Benhayon D, Zhang S, McCollum L, Schecter AD, Cheung JY, Sobie EA, Hajjar RJ, Lebeche D (2012) $\mathrm{Na}+/ \mathrm{Ca} 2$ + exchanger-1 protects against systolic failure in the Akitains 2 model of diabetic cardiomyopathy via a CXCR4/NF-kappaB pathway. Am J Physiol Heart Circ Physiol 303:H353-367. https://doi.org/10.1152/ajpheart.01198.2011

117. Lashin OM, Szweda PA, Szweda LI, Romani AM (2006) Decreased complex II respiration and HNE-modified SDH subunit in diabetic heart. Free Radic Biol Med 40:886-896. https:// doi.org/10.1016/j.freeradbiomed.2005.10.040

118. Lemieux H, Semsroth S, Antretter H, Hofer D, Gnaiger E (2011) Mitochondrial respiratory control and early defects of oxidative phosphorylation in the failing human heart. Int J Biochem Cell Biol 43:1729-1738. https://doi.org/10.1016/j.biocel.2011.08.008

119. Li J, Zhu H, Shen E, Wan L, Arnold JM, Peng T (2010) Deficiency of rac1 blocks NADPH oxidase activation, inhibits endoplasmic reticulum stress, and reduces myocardial remodeling in a mouse model of type 1 diabetes. Diabetes 59:2033-2042. https ://doi.org/10.2337/db09-1800

120. Li SY, Yang X, Ceylan-Isik AF, Du M, Sreejayan N, Ren J (2006) Cardiac contractile dysfunction in Lep/Lep obesity is accompanied by NADPH oxidase activation, oxidative modification of sarco(endo)plasmic reticulum Ca2 +-ATPase and myosin heavy chain isozyme switch. Diabetologia 49:1434-1446. https://doi. org/10.1007/s00125-006-0229-0
121. Li X, Wang H, Yao B, Xu W, Chen J, Zhou X (2016) lncRNA H19/miR-675 axis regulates cardiomyocyte apoptosis by targeting VDAC1 in diabetic cardiomyopathy. Sci Rep 6:36340. https ://doi.org/10.1038/srep36340

122. Liu JE, Palmieri V, Roman MJ, Bella JN, Fabsitz R, Howard BV, Welty TK, Lee ET, Devereux RB (2001) The impact of diabetes on left ventricular filling pattern in normotensive and hypertensive adults: the Strong Heart Study. J Am Coll Cardiol 37:1943-1949. https://doi.org/10.1016/S0735-1097(01)01230-X

123. Liu X, Xu Q, Wang X, Zhao Z, Zhang L, Zhong L, Li L, Kang W, Zhang Y, Ge Z (2015) Irbesartan ameliorates diabetic cardiomyopathy by regulating protein kinase $\mathrm{D}$ and $\mathrm{ER}$ stress activation in a type 2 diabetes rat model. Pharmacol Res 93:43-51. https:// doi.org/10.1016/j.phrs.2015.01.001

124. Liu ZW, Zhu HT, Chen KL, Dong X, Wei J, Qiu C, Xue JH (2013) Protein kinase RNA-like endoplasmic reticulum kinase (PERK) signaling pathway plays a major role in reactive oxygen species (ROS)-mediated endoplasmic reticulum stress-induced apoptosis in diabetic cardiomyopathy. Cardiovasc Diabetol 12:158. https://doi.org/10.1186/1475-2840-12-158

125. Lourenco AP, Leite-Moreira AF, Balligand JL, Bauersachs J, Dawson D, de Boer RA, de Windt LJ, Falcao-Pires I, FontesCarvalho R, Franz S, Giacca M, Hilfiker-Kleiner D, Hirsch E, Maack C, Mayr M, Pieske B, Thum T, Tocchetti CG, Brutsaert DL, Heymans S (2018) An integrative translational approach to study heart failure with preserved ejection fraction: a position paper from the Working Group on Myocardial Function of the European Society of Cardiology. Eur J Heart Fail 20:216-227. https://doi.org/10.1002/ejhf.1059

126. Lu H, Buchan RJ, Cook SA (2010) MicroRNA-223 regulates Glut4 expression and cardiomyocyte glucose metabolism. Cardiovasc Res 86:410-420. https://doi.org/10.1093/cvr/cvq010

127. Ma C, Luo H, Liu B, Li F, Tschope C, Fa X (2018) Long noncoding RNAs: a new player in the prevention and treatment of diabetic cardiomyopathy? Diabetes Metab Res Rev. https://doi. org/10.1002/dmrr.3056

128. Ma H, Li SY, Xu P, Babcock SA, Dolence EK, Brownlee M, Li J, Ren J (2009) Advanced glycation endproduct (AGE) accumulation and AGE receptor (RAGE) up-regulation contribute to the onset of diabetic cardiomyopathy. J Cell Mol Med 13:17511764. https://doi.org/10.1111/j.1582-4934.2008.00547.x

129. Ma J, Liu T, Wei AC, Banerjee P, O’Rourke B, Hart GW (2015) $\mathrm{O}$-GlcNAcomic profiling identifies widespread $O$-Linked beta- $N$-acetylglucosamine modification ( $O$-GlcNAcylation) in oxidative phosphorylation system regulating cardiac mitochondrial function. J Biol Chem 290:29141-29153. https://doi. org/10.1074/jbc.M115.691741

130. Maack C, Lehrke M, Backs J, Heinzel FR, Hulot JS, Marx N, Paulus WJ, Rossignol P, Taegtmeyer H, Bauersachs J, BayesGenis A, Brutsaert D, Bugger H, Clarke K, Cosentino F, De Keulenaer G, Dei Cas A, Gonzalez A, Huelsmann M, Iaccarino G, Lunde IG, Lyon AR, Pollesello P, Rena G, Riksen NP, Rosano G, Staels B, van Laake LW, Wanner C, Farmakis D, Filippatos G, Ruschitzka F, Seferovic P, de Boer RA, Heymans S (2018) Heart failure and diabetes: metabolic alterations and therapeutic interventions: a state-of-the-art review from the Translational Research Committee of the Heart Failure Association-European Society of Cardiology. Eur Heart J. https://doi.org/10.1093/eurhe artj/ehy596

131. Makino S, Kunimoto K, Muraoka Y, Mizushima Y, Katagiri K, Tochino Y (1980) Breeding of a non-obese, diabetic strain of mice. Jikken Dobutsu 29:1-13. https://doi.org/10.1538/expan im1978.29.1_1

132. Mali VR, Ning R, Chen J, Yang XP, Xu J, Palaniyandi SS (2014) Impairment of aldehyde dehydrogenase-2 by 4-hydroxy2-nonenal adduct formation and cardiomyocyte hypertrophy 
in mice fed a high-fat diet and injected with low-dose streptozotocin. Exp Biol Med (Maywood) 239:610-618. https://doi. org/10.1177/1535370213520109

133. Marwick TH, Ritchie R, Shaw JE, Kaye D (2018) Implications of underlying mechanisms for the recognition and management of diabetic cardiomyopathy. J Am Coll Cardiol 71:339-351. https ://doi.org/10.1016/j.jacc.2017.11.019

134. Mazumder PK, O’Neill BT, Roberts MW, Buchanan J, Yun UJ, Cooksey RC, Boudina S, Abel ED (2004) Impaired cardiac efficiency and increased fatty acid oxidation in insulin-resistant ob/ob mouse hearts. Diabetes 53:2366-2374. https://doi. org/10.2337/diabetes.53.9.2366

135. McGavock JM, Lingvay I, Zib I, Tillery T, Salas N, Unger R, Levine BD, Raskin P, Victor RG, Szczepaniak LS (2007) Cardiac steatosis in diabetes mellitus: a 1H-magnetic resonance spectroscopy study. Circulation 116:1170-1175. https://doi.org/10.1161/ CIRCULATIONAHA.106.645614

136. Mellor KM, Bell JR, Young MJ, Ritchie RH, Delbridge LM (2011) Myocardial autophagy activation and suppressed survival signaling is associated with insulin resistance in fructose-fed mice. J Mol Cell Cardiol 50:1035-1043. https://doi. org/10.1016/j.yjmcc.2011.03.002

137. Miettinen H, Lehto S, Salomaa V, Mahonen M, Niemela M, Haffner SM, Pyorala K, Tuomilehto J (1998) Impact of diabetes on mortality after the first myocardial infarction. The FINMONICA Myocardial Infarction Register Study Group. Diabetes Care 21:69-75. https://doi.org/10.2337/diacare.21.1.69

138. Mizushige K, Yao L, Noma T, Kiyomoto H, Yu Y, Hosomi N, Ohmori K, Matsuo H (2000) Alteration in left ventricular diastolic filling and accumulation of myocardial collagen at insulinresistant prediabetic stage of a type II diabetic rat model. Circulation 101:899-907. https://doi.org/10.1161/01.CIR.101.8.899

139. Monji A, Mitsui T, Bando YK, Aoyama M, Shigeta T, Murohara $\mathrm{T}$ (2013) Glucagon-like peptide-1 receptor activation reverses cardiac remodeling via normalizing cardiac steatosis and oxidative stress in type 2 diabetes. Am J Physiol Heart Circ Physiol 305:H295-304. https://doi.org/10.1152/ajpheart.00990.2012

140. Monkemann H, De Vriese AS, Blom HJ, Kluijtmans LA, Heil SG, Schild HH, Golubnitschaja O (2002) Early molecular events in the development of the diabetic cardiomyopathy. Amino Acids 23:331-336. https://doi.org/10.1007/s00726-001-0146-y

141. Montaigne D, Marechal X, Coisne A, Debry N, Modine T, Fayad G, Potelle C, El Arid JM, Mouton S, Sebti Y, Duez H, Preau S, Remy-Jouet I, Zerimech F, Koussa M, Richard V, Neviere R, Edme JL, Lefebvre P, Staels B (2014) Myocardial contractile dysfunction is associated with impaired mitochondrial function and dynamics in type 2 diabetic but not in obese patients. Circulation 130:554-564. https://doi.org/10.1161/CIRCULATIO NAHA.113.008476

142. Mouse Genome Sequencing C, Waterston RH, Lindblad-Toh K, Birney E, Rogers J, Abril JF, Agarwal P, Agarwala R, Ainscough $\mathrm{R}$, Alexandersson M, An P, Antonarakis SE, Attwood J, Baertsch R, Bailey J, Barlow K, Beck S, Berry E, Birren B, Bloom T, Bork P, Botcherby M, Bray N, Brent MR, Brown DG, Brown SD, Bult C, Burton J, Butler J, Campbell RD, Carninci P, Cawley S, Chiaromonte F, Chinwalla AT, Church DM, Clamp M, Clee C, Collins FS, Cook LL, Copley RR, Coulson A, Couronne O, Cuff J, Curwen V, Cutts T, Daly M, David R, Davies J, Delehaunty KD, Deri J, Dermitzakis ET, Dewey C, Dickens NJ, Diekhans M, Dodge S, Dubchak I, Dunn DM, Eddy SR, Elnitski L, Emes RD, Eswara P, Eyras E, Felsenfeld A, Fewell GA, Flicek P, Foley K, Frankel WN, Fulton LA, Fulton RS, Furey TS, Gage D, Gibbs RA, Glusman G, Gnerre S, Goldman N, Goodstadt L, Grafham D, Graves TA, Green ED, Gregory S, Guigo R, Guyer M, Hardison RC, Haussler D, Hayashizaki Y, Hillier LW, Hinrichs A, Hlavina W, Holzer T, Hsu F, Hua A, Hubbard T, Hunt A, Jackson
I, Jaffe DB, Johnson LS, Jones M, Jones TA, Joy A, Kamal M et al (2002) Initial sequencing and comparative analysis of the mouse genome. Nature 420:520-562. https://doi.org/10.1038/ nature 01262

143. Munasinghe PE, Riu F, Dixit P, Edamatsu M, Saxena P, Hamer NS, Galvin IF, Bunton RW, Lequeux S, Jones G, Lamberts RR, Emanueli C, Madeddu P, Katare R (2016) Type-2 diabetes increases autophagy in the human heart through promotion of Beclin-1 mediated pathway. Int J Cardiol 202:13-20. https://doi. org/10.1016/j.ijcard.2015.08.111

144. Nath S, Ghosh SK, Choudhury Y (2017) A murine model of type 2 diabetes mellitus developed using a combination of high fat diet and multiple low doses of streptozotocin treatment mimics the metabolic characteristics of type 2 diabetes mellitus in humans. $\mathrm{J}$ Pharmacol Toxicol Methods 84:20-30. https://doi.org/10.1016/j. vascn.2016.10.007

145. Ng AC, Delgado V, Bertini M, van der Meer RW, Rijzewijk LJ, Hooi Ewe S, Siebelink HM, Smit JW, Diamant M, Romijn JA, de Roos A, Leung DY, Lamb HJ, Bax JJ (2010) Myocardial steatosis and biventricular strain and strain rate imaging in patients with type 2 diabetes mellitus. Circulation 122:2538-2544. https://doi. org/10.1161/CIRCULATIONAHA.110.955542

146. Nichols BJ, Denton RM (1995) Towards the molecular basis for the regulation of mitochondrial dehydrogenases by calcium ions. Mol Cell Biochem 149-150:203-212. https://doi.org/10.1007/ BF01076578

147. Nielsen JM, Kristiansen SB, Norregaard R, Andersen CL, Denner L, Nielsen TT, Flyvbjerg A, Botker HE (2009) Blockage of receptor for advanced glycation end products prevents development of cardiac dysfunction in db/db type 2 diabetic mice. Eur J Heart Fail 11:638-647. https://doi.org/10.1093/eurjhf/hfp070

148. Norton GR, Candy G, Woodiwiss AJ (1996) Aminoguanidine prevents the decreased myocardial compliance produced by streptozotocin-induced diabetes mellitus in rats. Circulation 93:1905-1912. https://doi.org/10.1161/01.CIR.93.10.1905

149. Nozynski J, Zakliczynski M, Konecka-Mrowka D, Nikiel B, Mlynarczyk-Liszka J, Zembala-Nozynska E, Lange D, Maruszewski M, Zembala M (2009) Advanced glycation end products in the development of ischemic and dilated cardiomyopathy in patients with diabetes mellitus type 2. Transpl Proc 41:99-104. https:// doi.org/10.1016/j.transproceed.2008.09.065

150. Pacher P, Liaudet L, Soriano FG, Mabley JG, Szabo E, Szabo C (2002) The role of poly(ADP-ribose) polymerase activation in the development of myocardial and endothelial dysfunction in diabetes. Diabetes 51:514-521. https://doi.org/10.2337/diabe tes.51.2.514

151. Pereira L, Matthes J, Schuster I, Valdivia HH, Herzig S, Richard S, Gomez AM (2006) Mechanisms of [Ca2+]i transient decrease in cardiomyopathy of $\mathrm{db} / \mathrm{db}$ type 2 diabetic mice. Diabetes 55:608-615. https://doi.org/10.2337/diabetes.55.03.06. $\mathrm{db} 05-1284$

152. Peterson LR, Herrero P, Coggan AR, Kisrieva-Ware Z, Saeed I, Dence C, Koudelis D, McGill JB, Lyons MR, Novak E, DavilaRoman VG, Waggoner AD, Gropler RJ (2015) Type 2 diabetes, obesity, and sex difference affect the fate of glucose in the human heart. Am J Physiol Heart Circ Physiol 308:H1510-1516. https ://doi.org/10.1152/ajpheart.00722.2014

153. Peterson LR, Herrero P, Schechtman KB, Racette SB, Waggoner AD, Kisrieva-Ware Z, Dence C, Klein S, Marsala J, Meyer T, Gropler RJ (2004) Effect of obesity and insulin resistance on myocardial substrate metabolism and efficiency in young women. Circulation 109:2191-2196. https://doi.org/10.1161/01. CIR.0000127959.28627.F8

154. Phillips MS, Liu Q, Hammond HA, Dugan V, Hey PJ, Caskey CJ, Hess JF (1996) Leptin receptor missense mutation in the fatty 
Zucker rat. Nat Genet 13:18-19. https://doi.org/10.1038/ng059 6-18

155. Pugliese A (2017) Autoreactive T cells in type 1 diabetes. J Clin Invest 127:2881-2891. https://doi.org/10.1172/JCI94549

156. Pulinilkunnil T, Kienesberger PC, Nagendran J, Waller TJ, Young ME, Kershaw EE, Korbutt G, Haemmerle G, Zechner R, Dyck JR (2013) Myocardial adipose triglyceride lipase overexpression protects diabetic mice from the development of lipotoxic cardiomyopathy. Diabetes 62:1464-1477. https://doi.org/10.2337/ db12-0927

157. Qi Y, Zhu Q, Zhang K, Thomas C, Wu Y, Kumar R, Baker KM, Xu Z, Chen S, Guo S (2015) Activation of Foxo1 by insulin resistance promotes cardiac dysfunction and beta-myosin heavy chain gene expression. Circ Heart Fail 8:198-208. https://doi. org/10.1161/CIRCHEARTFAILURE.114.001457

158. Qin F, Siwik DA, Luptak I, Hou X, Wang L, Higuchi A, Weisbrod RM, Ouchi N, Tu VH, Calamaras TD, Miller EJ, Verbeuren TJ, Walsh K, Cohen RA, Colucci WS (2012) The polyphenols resveratrol and S17834 prevent the structural and functional sequelae of diet-induced metabolic heart disease in mice. Circulation 125(1757-1764):S1751-1756. https://doi.org/10.1161/ CIRCULATIONAHA.111.067801

159. Randle PJ, Newsholme EA, Garland PB (1964) Regulation of glucose uptake by muscle. 8 . Effects of fatty acids, ketone bodies and pyruvate, and of alloxan-diabetes and starvation, on the uptake and metabolic fate of glucose in rat heart and diaphragm muscles. Biochem J 93:652-665. https://doi.org/10.1042/bj093 0652

160. Reed MJ, Meszaros K, Entes LJ, Claypool MD, Pinkett JG, Gadbois TM, Reaven GM (2000) A new rat model of type 2 diabetes: the fat-fed, streptozotocin-treated rat. Metabolism 49:1390-1394. https://doi.org/10.1053/meta.2000.17721

161. Regan TJ, Lyons MM, Ahmed SS, Levinson GE, Oldewurtel HA, Ahmad MR, Haider B (1977) Evidence for cardiomyopathy in familial diabetes mellitus. J Clin Invest 60:884-899. https://doi. org/10.1172/JCI108843

162. Rerkpattanapipat P, D’Agostino RB Jr, Link KM, Shahar E, Lima JA, Bluemke DA, Sinha S, Herrington DM, Hundley WG (2009) Location of arterial stiffening differs in those with impaired fasting glucose versus diabetes: implications for left ventricular hypertrophy from the Multi-Ethnic Study of Atherosclerosis. Diabetes 58:946-953. https://doi.org/10.2337/db08-1192

163. Riehle C, Abel ED (2014) Insulin regulation of myocardial autophagy. Circ J 78:2569-2576. https://doi.org/10.1253/circj .CJ-14-1080

164. Riehle C, Abel ED (2016) Insulin signaling and heart failure. Circ Res 118:1151-1169. https://doi.org/10.1161/CIRCR ESAHA.116.306206

165. Riehle C, Abel ED (2012) PGC-1 proteins and heart failure. Trends Cardiovasc Med 22:98-105. https://doi.org/10.1016/j. tcm.2012.07.003

166. Riehle C, Wende AR, Sena S, Pires KM, Pereira RO, Zhu Y, Bugger H, Frank D, Bevins J, Chen D, Perry CN, Dong XC, Valdez S, Rech M, Sheng X, Weimer BC, Gottlieb RA, White MF, Abel ED (2013) Insulin receptor substrate signaling suppresses neonatal autophagy in the heart. J Clin Invest 123:5319-5333. https://doi.org/10.1172/JCI71171

167. Rijzewijk LJ, van der Meer RW, Smit JW, Diamant M, Bax JJ, Hammer S, Romijn JA, de Roos A, Lamb HJ (2008) Myocardial steatosis is an independent predictor of diastolic dysfunction in type 2 diabetes mellitus. J Am Coll Cardiol 52:1793-1799. https ://doi.org/10.1016/j.jacc.2008.07.062

168. Romanens M, Fankhauser S, Saner B, Michaud L, Saner H (1999) No evidence for systolic or diastolic left ventricular dysfunction at rest in selected patients with long-term type I diabetes mellitus. Eur J Heart Fail 1:169-175. https://doi.org/10.1016/ S1388-9842(99)00012-4

169. Rubler S, Dlugash J, Yuceoglu YZ, Kumral T, Branwood AW, Grishman A (1972) New type of cardiomyopathy associated with diabetic glomerulosclerosis. Am J Cardiol 30:595-602. https:// doi.org/10.1016/0002-9149(72)90595-4

170. Russo I, Frangogiannis NG (2016) Diabetes-associated cardiac fibrosis: cellular effectors, molecular mechanisms and therapeutic opportunities. J Mol Cell Cardiol 90:84-93. https://doi. org/10.1016/j.yjmcc.2015.12.011

171. Sakabe K, Wang Z, Hart GW (2010) Beta-N-acetylglucosamine (O-GlcNAc) is part of the histone code. Proc Natl Acad Sci USA 107:19915-19920. https://doi.org/10.1073/pnas.1009023107

172. Santos DL, Palmeira CM, Seica R, Dias J, Mesquita J, Moreno AJ, Santos MS (2003) Diabetes and mitochondrial oxidative stress: a study using heart mitochondria from the diabetic Goto-Kakizaki rat. Mol Cell Biochem 246:163-170. https://doi. org/10.1023/A:1023475022025

173. Sari FR, Watanabe K, Thandavarayan RA, Harima M, Zhang S, Muslin AJ, Kodama M, Aizawa Y (2010) 14-3-3 protein protects against cardiac endoplasmic reticulum stress (ERS) and ERSinitiated apoptosis in experimental diabetes. J Pharmacol Sci 113:325-334. https://doi.org/10.1254/jphs.10047FP

174. Schannwell CM, Schneppenheim M, Perings S, Plehn G, Strauer BE (2002) Left ventricular diastolic dysfunction as an early manifestation of diabetic cardiomyopathy. Cardiology 98:33-39. https://doi.org/10.1159/000064682

175. Seferovic PM, Petrie MC, Filippatos GS, Anker SD, Rosano G, Bauersachs J, Paulus WJ, Komajda M, Cosentino F, de Boer RA, Farmakis D, Doehner W, Lambrinou E, Lopatin Y, Piepoli MF, Theodorakis MJ, Wiggers H, Lekakis J, Mebazaa A, Mamas MA, Tschope C, Hoes AW, Seferovic JP, Logue J, McDonagh T, Riley JP, Milinkovic I, Polovina M, van Veldhuisen DJ, Lainscak M, Maggioni AP, Ruschitzka F, McMurray JJV (2018) Type 2 diabetes mellitus and heart failure: a position statement from the Heart Failure Association of the European Society of Cardiology. Eur J Heart Fail 20:853-872. https://doi.org/10.1002/ejhf.1170

176. Shantikumar S, Caporali A, Emanueli C (2012) Role of microRNAs in diabetes and its cardiovascular complications. Cardiovasc Res 93:583-593. https://doi.org/10.1093/cvr/cvr300

177. Sharma S, Adrogue JV, Golfman L, Uray I, Lemm J, Youker K, Noon GP, Frazier OH, Taegtmeyer H (2004) Intramyocardial lipid accumulation in the failing human heart resembles the lipotoxic rat heart. FASEB J 18:1692-1700. https://doi.org/10.1096/ f. $04-2263 \mathrm{com}$

178. Shen E, Diao X, Wang X, Chen R, Hu B (2011) MicroRNAs involved in the mitogen-activated protein kinase cascades pathway during glucose-induced cardiomyocyte hypertrophy. Am J Pathol 179:639-650. https://doi.org/10.1016/j.ajpat h.2011.04.034

179. Shen X, Zheng S, Metreveli NS, Epstein PN (2006) Protection of cardiac mitochondria by overexpression of MnSOD reduces diabetic cardiomyopathy. Diabetes 55:798-805. https://doi. org/10.2337/diabetes.55.03.06.db05-1039

180. Shen X, Zheng S, Thongboonkerd V, Xu M, Pierce WM Jr, Klein JB, Epstein PN (2004) Cardiac mitochondrial damage and biogenesis in a chronic model of type 1 diabetes. Am J Physiol Endocrinol Metab 287:E896-905. https://doi.org/10.1152/ajpen do.00047.2004

181. Shimizu I, Minamino T, Toko H, Okada S, Ikeda H, Yasuda N, Tateno K, Moriya J, Yokoyama M, Nojima A, Koh GY, Akazawa H, Shiojima I, Kahn CR, Abel ED, Komuro I (2010) Excessive cardiac insulin signaling exacerbates systolic dysfunction induced by pressure overload in rodents. J Clin Invest 120:15061514. https://doi.org/10.1172/JCI40096 
182. Shimizu M, Umeda K, Sugihara N, Yoshio H, Ino H, Takeda R, Okada Y, Nakanishi I (1993) Collagen remodelling in myocardia of patients with diabetes. J Clin Pathol 46:32-36. https://doi. org/10.1136/jcp.46.1.32

183. Shimomura I, Hammer RE, Richardson JA, Ikemoto S, Bashmakov Y, Goldstein JL, Brown MS (1998) Insulin resistance and diabetes mellitus in transgenic mice expressing nuclear SREBP$1 \mathrm{c}$ in adipose tissue: model for congenital generalized lipodystrophy. Genes Dev 12:3182-3194. https://doi.org/10.1101/ gad.12.20.3182

184. Shivalkar B, Dhondt D, Goovaerts I, Van Gaal L, Bartunek J, Van Crombrugge P, Vrints C (2006) Flow mediated dilatation and cardiac function in type 1 diabetes mellitus. Am J Cardiol 97:77-82. https://doi.org/10.1016/j.amjcard.2005.07.111

185. Singh VP, Bali A, Singh N, Jaggi AS (2014) Advanced glycation end products and diabetic complications. Korean J Physiol Pharmacol 18:1-14. https://doi.org/10.4196/kjpp.2014.18.1.1

186. Singh VP, Le B, Bhat VB, Baker KM, Kumar R (2007) Highglucose-induced regulation of intracellular ANG II synthesis and nuclear redistribution in cardiac myocytes. Am J Physiol Heart Circ Physiol 293:H939-948. https://doi.org/10.1152/ajphe art.00391.2007

187. Singh VP, Le B, Khode R, Baker KM, Kumar R (2008) Intracellular angiotensin II production in diabetic rats is correlated with cardiomyocyte apoptosis, oxidative stress, and cardiac fibrosis. Diabetes 57:3297-3306. https://doi.org/10.2337/db08-0805

188. Song X, Zheng X, Malbon CC, Wang H (2001) Galpha i2 enhances in vivo activation of and insulin signaling to GLUT4. J Biol Chem 276:34651-34658. https://doi.org/10.1074/jbc. M105894200

189. Sorop O, Heinonen I, van Kranenburg M, van de Wouw J, de Beer VJ, Nguyen ITN, Octavia Y, van Duin RWB, Stam K, van Geuns RJ, Wielopolski PA, Krestin GP, van den Meiracker AH, Verjans R, van Bilsen M, Danser AHJ, Paulus WJ, Cheng C, Linke WA, Joles JA, Verhaar MC, van der Velden J, Merkus D, Duncker DJ (2018) Multiple common comorbidities produce left ventricular diastolic dysfunction associated with coronary microvascular dysfunction, oxidative stress, and myocardial stiffening. Cardiovasc Res 114:954-964. https://doi.org/10.1093/cvr/cvy03 8

190. Suarez J, Scott B, Dillmann WH (2008) Conditional increase in SERCA2a protein is able to reverse contractile dysfunction and abnormal calcium flux in established diabetic cardiomyopathy. Am J Physiol Regul Integr Comp Physiol 295:R1439-1445. https ://doi.org/10.1152/ajpregu.00736.2007

191. Thum T (2014) Noncoding RNAs and myocardial fibrosis. Nat Rev Cardiol 11:655-663. https://doi.org/10.1038/nrcar dio.2014.125

192. Thum T, Gross C, Fiedler J, Fischer T, Kissler S, Bussen M, Galuppo P, Just S, Rottbauer W, Frantz S, Castoldi M, Soutschek J, Koteliansky V, Rosenwald A, Basson MA, Licht JD, Pena JT, Rouhanifard SH, Muckenthaler MU, Tuschl T, Martin GR, Bauersachs J, Engelhardt S (2008) MicroRNA-21 contributes to myocardial disease by stimulating MAP kinase signalling in fibroblasts. Nature 456:980-984. https://doi.org/10.1038/natur e07511

193. Tikellis C, Thomas MC, Harcourt BE, Coughlan MT, Pete J, Bialkowski K, Tan A, Bierhaus A, Cooper ME, Forbes JM (2008) Cardiac inflammation associated with a Western diet is mediated via activation of RAGE by AGEs. Am J Physiol Endocrinol Metab 295:E323-330. https://doi.org/10.1152/ajpendo.00024 2008

194. Trajkovski M, Hausser J, Soutschek J, Bhat B, Akin A, Zavolan M, Heim MH, Stoffel M (2011) MicroRNAs 103 and 107 regulate insulin sensitivity. Nature 474:649-653. https://doi. org/10.1038/nature10112
195. Trost SU, Belke DD, Bluhm WF, Meyer M, Swanson E, Dillmann WH (2002) Overexpression of the sarcoplasmic reticulum $\mathrm{Ca}(2+)$-ATPase improves myocardial contractility in diabetic cardiomyopathy. Diabetes 51:1166-1171. https://doi. org/10.2337/diabetes.51.4.1166

196. Tschope C, Walther T, Escher F, Spillmann F, Du J, Altmann C, Schimke I, Bader M, Sanchez-Ferrer CF, Schultheiss HP, Noutsias M (2005) Transgenic activation of the kallikrein-kinin system inhibits intramyocardial inflammation, endothelial dysfunction and oxidative stress in experimental diabetic cardiomyopathy. FASEB J 19:2057-2059. https://doi.org/10.1096/fj.054095fje

197. Tsushima K, Bugger H, Wende AR, Soto J, Jenson GA, Tor AR, McGlauflin R, Kenny HC, Zhang Y, Souvenir R, Hu XX, Sloan CL, Pereira RO, Lira VA, Spitzer KW, Sharp TL, Shoghi KI, Sparagna GC, Rog-Zielinska EA, Kohl P, Khalimonchuk O, Schaffer JE, Abel ED (2018) Mitochondrial reactive oxygen species in lipotoxic hearts induce post-translational modifications of AKAP121, DRP1, and OPA1 that promote mitochondrial fission. Circ Res 122:58-73. https://doi.org/10.1161/CIRCR ESAHA.117.311307

198. Turdi S, Kandadi MR, Zhao J, Huff AF, Du M, Ren J (2011) Deficiency in AMP-activated protein kinase exaggerates high fat diet-induced cardiac hypertrophy and contractile dysfunction. J Mol Cell Cardiol 50:712-722. https://doi.org/10.1016/j.yjmcc .2010.12.007

199. Turko IV, Li L, Aulak KS, Stuehr DJ, Chang JY, Murad F (2003) Protein tyrosine nitration in the mitochondria from diabetic mouse heart. Implications to dysfunctional mitochondria in diabetes. J Biol Chem 278:33972-33977. https://doi.org/10.1074/ jbc.M303734200

200. Turko IV, Murad F (2003) Quantitative protein profiling in heart mitochondria from diabetic rats. J Biol Chem 278:35844-35849. https://doi.org/10.1074/jbc.M303139200

201. Usui I, Imamura T, Satoh H, Huang J, Babendure JL, Hupfeld CJ, Olefsky JM (2004) GRK2 is an endogenous protein inhibitor of the insulin signaling pathway for glucose transport stimulation. EMBO J 23:2821-2829. https://doi.org/10.1038/sj.emboj.76002 97

202. Van den Bergh A, Vanderper A, Vangheluwe P, Desjardins F, Nevelsteen I, Verreth W, Wuytack F, Holvoet P, Flameng W, Balligand JL, Herijgers P (2008) Dyslipidaemia in type II diabetic mice does not aggravate contractile impairment but increases ventricular stiffness. Cardiovasc Res 77:371-379. https://doi. org/10.1093/cvr/cvm001

203. Van Linthout S, Seeland U, Riad A, Eckhardt O, Hohl M, Dhayat N, Richter U, Fischer JW, Bohm M, Pauschinger M, Schultheiss HP, Tschope C (2008) Reduced MMP-2 activity contributes to cardiac fibrosis in experimental diabetic cardiomyopathy. Basic Res Cardiol 103:319-327. https://doi.org/10.1007/s0039 5-008-0715-2

204. Viereck J, Thum T (2017) Long noncoding RNAs in pathological cardiac remodeling. Circ Res 120:262-264. https://doi. org/10.1161/CIRCRESAHA.116.310174

205. Vincent HK, Powers SK, Dirks AJ, Scarpace PJ (2001) Mechanism for obesity-induced increase in myocardial lipid peroxidation. Int J Obes Relat Metab Disord 25:378-388. https://doi. org/10.1038/sj.ijo.0801536

206. Wallace DC (1992) Mitochondrial genetics: a paradigm for aging and degenerative diseases? Science 256:628-632. https://doi. org/10.1126/science. 1533953

207. Wang B, Yang Q, Sun YY, Xing YF, Wang YB, Lu XT, Bai WW, Liu XQ, Zhao YX (2014) Resveratrol-enhanced autophagic flux ameliorates myocardial oxidative stress injury in diabetic mice. J Cell Mol Med 18:1599-1611. https://doi.org/10.1111/ jcmm.12312 
208. Wang P, Lloyd SG, Zeng H, Bonen A, Chatham JC (2005) Impact of altered substrate utilization on cardiac function in isolated hearts from Zucker diabetic fatty rats. Am J Physiol Heart Circ Physiol 288:H2102-2110. https://doi.org/10.1152/ajphe art.00935.2004

209. Wang Q, Liu Y, Fu Q, Xu B, Zhang Y, Kim S, Tan R, Barbagallo F, West T, Anderson E, Wei W, Abel ED, Xiang YK (2017) Inhibiting insulin-mediated beta2-adrenergic receptor activation prevents diabetes-associated cardiac dysfunction. Circulation 135:73-88. https://doi.org/10.1161/CIRCULATIO NAHA.116.022281

210. Wang Y, Sun W, Du B, Miao X, Bai Y, Xin Y, Tan Y, Cui W, Liu B, Cui T, Epstein PN, Fu Y, Cai L (2013) Therapeutic effect of MG-132 on diabetic cardiomyopathy is associated with its suppression of proteasomal activities: roles of Nrf2 and NFkappaB. Am J Physiol Heart Circ Physiol 304:H567-578. https ://doi.org/10.1152/ajpheart.00650.2012

211. Warden CH, Fisler JS (2008) Comparisons of diets used in animal models of high-fat feeding. Cell Metab 7:277. https://doi. org/10.1016/j.cmet.2008.03.014

212. Wende AR (2016) Post-translational modifications of the cardiac proteome in diabetes and heart failure. Proteomics Clin Appl 10:25-38. https://doi.org/10.1002/prca.201500052

213. Wende AR, Symons JD, Abel ED (2012) Mechanisms of lipotoxicity in the cardiovascular system. Curr Hypertens Rep 14:517531. https://doi.org/10.1007/s11906-012-0307-2

214. Westermann D, Rutschow S, Jager S, Linderer A, Anker S, Riad A, Unger T, Schultheiss HP, Pauschinger M, Tschope C (2007) Contributions of inflammation and cardiac matrix metalloproteinase activity to cardiac failure in diabetic cardiomyopathy: the role of angiotensin type 1 receptor antagonism. Diabetes 56:641-646. https://doi.org/10.2337/db06-1163

215. Westermann D, Rutschow S, Van Linthout S, Linderer A, Bucker-Gartner C, Sobirey M, Riad A, Pauschinger M, Schultheiss HP, Tschope C (2006) Inhibition of p38 mitogen-activated protein kinase attenuates left ventricular dysfunction by mediating pro-inflammatory cardiac cytokine levels in a mouse model of diabetes mellitus. Diabetologia 49:2507-2513. https://doi. org/10.1007/s00125-006-0385-2

216. Westermann D, Van Linthout S, Dhayat S, Dhayat N, Escher F, Bucker-Gartner C, Spillmann F, Noutsias M, Riad A, Schultheiss HP, Tschope C (2007) Cardioprotective and anti-inflammatory effects of interleukin converting enzyme inhibition in experimental diabetic cardiomyopathy. Diabetes 56:1834-1841. https://doi. org/10.2337/db06-1662

217. Westermann D, Van Linthout S, Dhayat S, Dhayat N, Schmidt A, Noutsias M, Song XY, Spillmann F, Riad A, Schultheiss HP, Tschope C (2007) Tumor necrosis factor-alpha antagonism protects from myocardial inflammation and fibrosis in experimental diabetic cardiomyopathy. Basic Res Cardiol 102:500-507. https ://doi.org/10.1007/s00395-007-0673-0

218. Wilson RD, Islam MS (2012) Fructose-fed streptozotocininjected rat: an alternative model for type 2 diabetes. Pharmacol Rep 64:129-139. https://doi.org/10.1016/S1734-1140(12)70739 $-9$

219. Wright JJ, Kim J, Buchanan J, Boudina S, Sena S, Bakirtzi K, Ilkun O, Theobald HA, Cooksey RC, Kandror KV, Abel ED (2009) Mechanisms for increased myocardial fatty acid utilization following short-term high-fat feeding. Cardiovasc Res 82:351-360. https://doi.org/10.1093/cvr/cvp017

220. Xiang Y, Kobilka BK (2003) Myocyte adrenoceptor signaling pathways. Science 300:1530-1532. https://doi.org/10.1126/scien ce.1079206
221. Xie Z, Lau K, Eby B, Lozano P, He C, Pennington B, Li H, Rathi S, Dong Y, Tian R, Kem D, Zou MH (2011) Improvement of cardiac functions by chronic metformin treatment is associated with enhanced cardiac autophagy in diabetic OVE26 mice. Diabetes 60:1770-1778. https://doi.org/10.2337/db10-0351

222. Xu J, Wang G, Wang Y, Liu Q, Xu W, Tan Y, Cai L (2009) Diabetes- and angiotensin II-induced cardiac endoplasmic reticulum stress and cell death: metallothionein protection. J Cell Mol Med 13:1499-1512. https://doi.org/10.1111/j.1582-4934.2009.00833 .x

223. Xu Z, Tong Q, Zhang Z, Wang S, Zheng Y, Liu Q, Qian LB, Chen SY, Sun J, Cai L (2017) Inhibition of HDAC3 prevents diabetic cardiomyopathy in OVE26 mice via epigenetic regulation of DUSP5-ERK1/2 pathway. Clin Sci (Lond) 131:1841-1857. https://doi.org/10.1042/CS20170064

224. Yagyu H, Chen G, Yokoyama M, Hirata K, Augustus A, Kako Y, Seo T, Hu Y, Lutz EP, Merkel M, Bensadoun A, Homma S, Goldberg IJ (2003) Lipoprotein lipase (LpL) on the surface of cardiomyocytes increases lipid uptake and produces a cardiomyopathy. J Clin Invest 111:419-426. https://doi.org/10.1172/ JCI16751

225. Yang Q, Gao H, Dong R, Wu YQ (2016) Sequential changes of endoplasmic reticulum stress and apoptosis in myocardial fibrosis of diabetes mellitus-induced rats. Mol Med Rep 13:5037-5044. https://doi.org/10.3892/mmr.2016.5180

226. Ye G, Metreveli NS, Donthi RV, Xia S, Xu M, Carlson EC, Epstein PN (2004) Catalase protects cardiomyocyte function in models of type 1 and type 2 diabetes. Diabetes 53:1336-1343. https://doi.org/10.2337/diabetes.53.5.1336

227. Yoshioka M, Kayo T, Ikeda T, Koizumi A (1997) A novel locus, Mody4, distal to D7Mit189 on chromosome 7 determines earlyonset NIDDM in nonobese C57BL/6 (Akita) mutant mice. Diabetes 46:887-894. https://doi.org/10.2337/diab.46.5.887

228. Young ME, Guthrie PH, Razeghi P, Leighton B, Abbasi S, Patil S, Youker KA, Taegtmeyer H (2002) Impaired long-chain fatty acid oxidation and contractile dysfunction in the obese Zucker rat heart. Diabetes 51:2587-2595. https://doi.org/10.2337/diabe tes.51.8.2587

229. Zarich SW, Arbuckle BE, Cohen LR, Roberts M, Nesto RW (1988) Diastolic abnormalities in young asymptomatic diabetic patients assessed by pulsed Doppler echocardiography. J Am Coll Cardiol 12:114-120. https://doi.org/10.1016/07351097(88)90364-6

230. Zhao XY, Hu SJ, Li J, Mou Y, Chen BP, Xia Q (2006) Decreased cardiac sarcoplasmic reticulum Ca2 +-ATPase activity contributes to cardiac dysfunction in streptozotocin-induced diabetic rats. J Physiol Biochem 62:1-8. https://doi.org/10.1007/BF031 65800

231. Zhao Y, Zhang L, Qiao Y, Zhou X, Wu G, Wang L, Peng Y, Dong X, Huang H, Si L, Zhang X, Zhang L, Li J, Wang W, Zhou L, Gao X (2013) Heme oxygenase-1 prevents cardiac dysfunction in streptozotocin-diabetic mice by reducing inflammation, oxidative stress, apoptosis and enhancing autophagy. PLoS One 8:e75927. https://doi.org/10.1371/journal.pone.0075927

232. Zhou YT, Grayburn P, Karim A, Shimabukuro M, Higa M, Baetens D, Orci L, Unger RH (2000) Lipotoxic heart disease in obese rats: implications for human obesity. Proc Natl Acad Sci USA 97:1784-1789. https://doi.org/10.1073/pnas.97.4.1784

233. Zhu-Mauldin X, Marsh SA, Zou L, Marchase RB, Chatham JC (2012) Modification of STIM1 by $O$-linked $N$-acetylglucosamine (O-GlcNAc) attenuates store-operated calcium entry in neonatal cardiomyocytes. J Biol Chem 287:39094-39106. https://doi. org/10.1074/jbc.M112.383778 